\title{
BĂILE ROMANE DE LA ALBURNUS MAIOR, DEALUL CARPENI - EDIFICIUL E2. RAPORT ARHEOLOGIC ${ }^{1}$
}

\author{
OVIDIU ȚENTEA, VALENTIN VOIȘIAN
}

\section{THE ROMAN BATHS AT ALBURNUS MAIOR, CARPENI HILL - EDIFICE E2. ARCHAEOLOGICAL REPORT}

Alburnus Maior has a special place in the scholarly literature due to a series of exceptional discoveries made in here since the beginning of the $19^{\text {th }} \mathrm{c}$. up to nowadays. Until 2000 the artefacts discovered at Roşia Montană came from stray finds, after that year large-scale preventive archaeological excavations were undertaken on site. As a result, from 2001 to 2012 were investigated ancient mining galleries, worship places, habitation areas and cemeteries.

Located in the central part of Roşia Montană, the Carpeni Hill was in time one of the find spots for a consistent number of inscriptions. Recent archaeological excavations made in this area, in the framework of "Alburnus Maior" National Research Program, led to the discovery of a small cluster of dwellings and two groups of graves on the north-western part of the site, as well as two edifices with hypocaustum, namely E1 to the south-eastern extremity of the site and E2 to the central part of the site, on the so-called spot Bisericuță. The results of the archaeological investigations made in 2001 were published as a preliminary report (Tentea, Voişian 2003a, 447-467). This paper represents the archaeological report of the excavations made in 20022003 in the Roman bath house E2 on Carpeni Hill.

KEYWORDS: Roman Dacia, Alburnus Maior, balnea, Silvanus, brick stamps CUVINTE CHEIE: Dacia romană, Alburnus Maior, balnea, Silvanus, ştampile

Alburnus Maior se bucură de un loc aparte în literatura istorică de specialitate datorită unor descoperiri de excepţie, efectuate începând cu secolul al XLX-lea şi care au continuat până de curând. Dacă până în anul 2000, descoperirile de la Roşia Montană au avut un caracter fortuit, ulterior acestea au survenit în contextul unui amplu demers de cercetare arheologică preventivă. Astfel, în perioada anilor 2001-2012, aici au fost cercetate arheologic galerii antice de mină, locuri de cult, elemente de habitat sau necropole ${ }^{2}$.

Situat în zona centrală a Roşiei Montane, Dealul Carpeni a fost de-a lungul timpului unul dintre locurile de unde provine un număr însemnat de descoperiri epigrafice ${ }^{3}$. Cercetările arheologice de datã mai recentã în arealul Dealului Carpeni, efectuate în cadrul Programului Național de Cercetare „Alburnus Maior”, publicate preliminar într-o sinteză a descoperirilor din anul 2001, au evidenţiat un grup restrâns de locuințe şi două grupuri de morminte, în zona nordvestică $^{4}$, precum şi două edificii prevăzute cu instalaţie de hypocaustum: $\mathrm{El}^{5}$, în extremitatea sud-

\footnotetext{
I Studiul a fost redactat de Ovidiu Țentea. Pentru raportul primei campanii, din anul 2001, vezi Țentea, Voişian 2003a, 447-467. Cu această ocazie doresc să le mulțumesc celor care au contribuit la realizarea documentației complete a acestei cercetări, din aceasta fiind prezentată numai raportul cercetării arheologice: doamnei arhitect Anișoara Sion (pentru planul general al clădirii și profilele altimetrice), dr. Felix Marcu (pentru sprijinul acordat în timpul participării sale la cercetările din anul 2003), arhitect Andrei Cîmpeanu (pentru realizarea grafică a unor planșe), dr. Cristian Găzdac (pentru determinarea monedelor) și doamnei Doina Boroș (pentru efectuarea analizelor chimice ale fragmentelor de tencuială pictată).

Această lucrare a fost realizată în cadrul proiectului finanţat de Ministerul Educației Naţionale, CNCS - UEFISCDI, nr. PN-II-ID-PCE-2012-4-0210.

2 Pentru o sintezã tehnicã a descoperirilor și o evaluare din perspectivã managerială a programului, vezi Damian, Borş 2007-2008, 481 și urm.

${ }^{3}$ Despre descoperirile epigrafice din zonă: IDR III/3, 383, 388-390, 393, 398-400, 402, 403, 409, 426; RRS, 160, nr. 4; 161 nr. 20. Aici s-a presupus existența unei fortificații romane - vezi Moga 1985, 57; IDR III/3, p. 383. Alte descoperiri au fost făcute în zona nordică a masivului (proprietatea familiei Bădău), precum şi în partea sudică a dealului (vezi Țentea 2003, 253-255).

${ }^{4}$ Rusu-Bolindet et alii 2003, 387-431

${ }^{5}$ Bota, Tentea, Voişian 2003, 433-446
} 
estică, respectiv E2, în zona centrală a dealului, în punctul numit „Bisericuţă ”ø . Cercetarea arheologică a clădirii E2 a continuat ulterior prin două campanii succesive, desfăşurate în anii 2002 și 2003. Rezultatele preliminare ale acestora sunt prezentate în cele ce urmează.

Deşi, după cum am mai amintit cu alte ocazii ${ }^{7}$, literatura de specialitate include un număr însemnat de referiri la descoperirile făcute în acest punct anterior anului 2000 , informaţiile sunt destul de imprecise. Astfel, descoperiri ale unor materiale provenind dintr-o clădire cu instalaţie de hypocaustum au fost menţionate în trecut, cu prilejul unor discuții referitoare la prezenţa legiunii XIII Gemina la Alburnus Maior. Inițial, Volker Wollmann semnala descoperiri de cărămizi în zona Carpeni $^{8}$, pentru ca ulterior să amintească și de o ștampilă aparţinând legiunii în discuție, piesă găsită în urma unor investigații în anul $1986^{9}$. Urme ale unor astfel de sondajele le-am putut sesiza parțial în cursul cercetărilor noastre din anul $2001^{10}$. Ca urmare a cercetării extensive a clădirii E2, realizată în următorii doi ani, am identificat o serie de alte detalii semnificative ale acestor intervenții din anii ' 60 ai secolului trecut. Așadar, pe substrucţia pavimentului subsolului încăperii $\mathrm{D}$ a fost identificată o aglomeraţie de pietre fasonate de carieră, dispuse neregulat pe un aliniament de cca $2 \mathrm{~m}$, orientat aproximativ NE-SV. Acestea erau stivuite de-a lungul unei intervenţii „arheologice", fie pentru consolidarea marginilor unei tranșee, fie - mai degrabă - din considerente legate de o "raționalizare" a efectivelor implicate în excavare, fiind vorba de o cantitate apreciabilă de piatră care nu a mai fost evacuată din săpătură $(\mathbf{P l}$. IX/2-4, în centrul imaginii). Prin săparea entuziastă a acestei tranşee a fost distrus complet colţul sud-estic al clădirii şi o porțiune de peste 3 $\mathrm{m}$ din zidul Z9, lat de $1,15 \mathrm{~m}$ și înalt de peste $2 \mathrm{~m}$. Săpătura a fost oprită la nivelul substrucției de piatră de râu a şapei de mortar, distrusă la rândul ei, care nivela subsolul camerelor $A^{\prime}$ şi $D^{\prime}$. De asemenea, traiectul acestei tranşee a distrus jumătatea sudică a zidul Z8 şi - aproape complet traiectul zidului perimetral sudic, Z10 (PI. IX/5).

Aceste intervenții, care au precedat cercetarea arheologică propriu-zisă a clădirii, au distrus cea mai mare parte a relațiilor stratigrafice în plan orizontal, ceea ce a determinat imposibilitatea stabilirii unor corelări între nivelurile de utilizare ale diferitelor camere. În egală măsură, necesitatea defrişării unei vegetații forestiere destul de abundente a determinat adaptarea continuă a sistemului de săpătură, fiind luată în considerare o planificare atentă a extinderii cercetării pentru excavarea şi depozitarea unui volum mare de dărâmătură, dat fiind spațiul redus avut la dispoziție. Cercetarea în suprafețe extinse a constituit, de asemenea, singura posibilitate de a identifica și înlătura intervențiile arheologice contemporane, care se distingeau destul de anevoios de stratul de demolare al zidurilor, fapt complicat şi de nevoia înlăturării atente a rădăcinilor de copaci. O intervenție semnificativă a fost observată în partea vestică a edificiului, unde zidurile au fost distruse integral până la nivelul stâncii native (PI. IX/3). În urma unor discuții purtate în anul 2010 cu domnul ing. Aurel Sântimbreanu, un bun cunoscător al patrimoniului arheologic de la Roșia Montană, am putut verifica unele informații orale, pe care le obținusem anterior, cu privire la săpăturile întreprinse sub conducerea sa între 1966-1967 (Pl. IX/1). Schița şi descrierile, cu toate că au fost efectuate după o perioadă de timp considerabilă de la data efectuării acelor intervenții, mi-au fost de un real folos pentru înțelegerea modalității în care au fost făcute acele excavații. După identificarea unor ziduri, cu distanța între ele de aproximativ $18 \mathrm{~m}$, acestea au fost „urmărite”, conturându-se o suprafață cu lungimea de 18-20 m şi lățimea de 10-12 m. În acest fel, a fost identificat material ceramic de construcție, o ștampilă a legiunii XIII Gemina și alte fragmente de ceramică ${ }^{\prime l}$. Investigațiile par să fi avut ca obiectiv identificare unei ștampile, care ar fi atestat prezența legiunii amintite la Alburnus Maior. Din câte am putut deduce, coroborând mai multe informații verbale, îndeplinirea acestui deziderat a coincis cu finalizarea acelor săpături.

6 Tentea, Voişian 2003, 447-467

7 Țentea 2003, 253-254; Țentea 2009, 372

8 Wollmann 1979, 197

${ }^{9}$ Wollmann 1985-1986, 295, nota 80; Wollmann 1996, 74; Sântimbreanu 1989, 20

${ }^{10}$ Tentea, Voişian 2003a, 447, 461 - S24 profil est, între metri 2-7

" Scrisoarea lui Aurel Sântimbreanu este datată din 12 martie 2010 şi face parte din arhiva personală a subsemnatului. Îi mulțumesc şi pe această cale pentru aceastã mărturie. 
Planul edificiului E2 este compact, înscriindu-se într-o suprafaţă aproximativ pătrată, cu laturile de $17,50 \mathrm{~m}$ pe direcţia N-S şi $19,50 \mathrm{~m}$ pe direcţia E-V, având o suprafață de cca $340 \mathrm{~m} . p$. Trama zidurilor a fost orientată aproximativ pe direcţia EV-NS (PI. III).

Zidurile au fost construite în tehnica opus incertum, utilizându-se și fragmente de cărămidă. Liantul a fost realizat din mortar de var în amestec cu nisip şi pietriş. Pietrele utilizate în construcţie au fost variate, atât în privinţa dimensiunilor, cât şi din punct de vedere structural şi calitativ. Pietrele de zidărie mai friabile, destul de reduse cantitativ, sunt asemănătoare structural cu stratul de rocă superficială a Dealului Carpeni. Acestea provin probabil din nivelarea spațiului destinat construcţiei, respectiv din săparea șanţurilor pentru fundaţii. Pentru consolidarea muchiilor clădiril au fost utilizate blocuri paralelipipedice de calcar de dimensiuni considerabile $(0,80 / 1 \times$ $0,40 / 0,50 \times 0,40 / 50 \mathrm{~m})^{12}$.

Au fost identificate trei faze de construcţie şi reparaţie, asociate cu modificări ale spaţiului şi schimbarea funcționalității unor încăperi, posibil a întregii clădiri, în ultima sa etapă de funcționare. În primele două faze, în edificiu funcţiona cu siguranță o baie publică. Refacerea integrală a planului construcţiei, din faza a treia, corespunde cu o posibilă schimbare a destinaţiei clădirii, instalaţia de încălzire cu hypocaustum fiind dezafectată în anumite porţiuni.

În prima fază, construcţia cuprindea cel puţin trei camere încălzite $\left(A, A^{\prime}\right.$ şi $\left.D\right)$, precum şi spaţiul de serviciu $C$ (acesta adăpostea gurile de praefurnium, delimitat spre nord de zidul Z6). La vest de camera $\mathrm{A}$, fragmentele de ziduri păstrate in situ din această fază indică un mic compartiment $\mathrm{B}^{2}$, cu deschiderile interioare de $2,30 \times 1,50(1,80) \mathrm{m}$, în care este posibil să fi funcţionat un bazin cu apă rece - frigidarium, drenat în canalul $\mathrm{cl}$.

Zidurile clădirii din faza 1 au fost realizate în mare parte din piatră de culoare roșiatică friabilă, legatã cu mortar de culoare alb-roșcată. Pietrele sunt dispuse ordonat în asize succesive, aproximativ orizontale. Grosimea zidurilor este considerabilă, ajungând în cazul celor orientate $\mathrm{N}$ S până la $1,00 \mathrm{~m}$; nu a putut fi determinată grosimea zidului $Z 9$, care limita la est încăperea $D$, care ajunge în ultima fază până la $1,15 \mathrm{~m}$. Este de menționat faptul că în unele porțiuni fundaţiile au fost realizate prin săparea unor șanțuri în stânca nativă, destul de friabilă.

În faza a doua a băilor E2, zidurile sunt reconstruite în unele zone încă de la nivelul pereților subsolului, suprapunându-le pe cele anterioare, dar având o grosime mult mai mică $(0,65-$ $0,70 \mathrm{~m})$. Zidurile din această fază au fost conservate pe o înălțime ceva mai mare, de până la 0,60 m înălțime. Mortarul folosit în această construcţie are structură și aspect diferit, fiind mai fin și de culoare alb-cenuşie. Aparent, pietrele de carieră sunt de dimensiuni ceva mai mici decât cele din zidurile fazei anterioare, fiind dispuse destul de aleatoriu în cadrul aceleiași asize de construcție.

Se poate observa o extindere a construcţiei spre vest şi spre nord (PI. XIV). Planul băii se compune din cinci încăperi: A, D, B, B' și I - bazinul de apă rece - frigidarium, situat la vest de zidul Z5, ca o anexă (Pl. VIII/1, 3; XIV). La acestea se adaugă un spaţiu de serviciu - C. Camerele A, D şi B aveau subsolul încălzit. În subsolul camerei B' nu au fost identificate elemente ale unei instalații de încălzire, nivelul stâncii native fiind relativ ridicat. La nord de camera A, în spațiul C, construit în această fază, între zidurile Z1, prelungirea lui Z2 spre nord și Z6, se aflau probabil două guri de praefurnia, care comunicau cu încăperile din zona nordică a clădirii prin canale care traversau zidurile despărţitoare de la nivelul subsolului. Pe zidul Z2 se observă clar conturat, la nivelul pardoselii, un spaţiu gol din care începe canalul cl. Acest fapt indică proximitatea unui bazin de apă caldă.

Datorită unor urme de săruri puternic sedimentate pe faţa superioară a zidului Z9, dar şi datorită vecinătătii unui praefurnium, putem presupune că un alt bazin de apă caldă ar fi putut funcționa în interiorul camerei $\mathrm{D}$, foarte aproape de zidul $\mathrm{Z9}$.

Încăperea B a fost concepută iniţial (faza 2), ca un spaţiu neîncălzit, fără subsol, acesta realizându-se prin decuparea stâncii din spaţiul cuprins între zidurile Z2, Z3, Z5 și Z6, la cca 10-12 cm în exteriorul feței acestora. Baza zidurilor Z5 şi Z6, la nivelul subsolului, a fost constituită din stânca nativă. Cota maximă superioară până la care se mai păstrează stânca este mai înaltă cu 0,45 $\mathrm{m}$ fată de cota nivelului subsolului. O situație aparte a putut fi observată pe traiectul zidului Z3. Pe o porțiune a acestuia s-a putut constata faptul că talpa fundaţiei era cu $20-30 \mathrm{~cm}$ mai ridicată față

\footnotetext{
${ }^{12}$ Pentru câteva situații reprezentative de la Ostia, vezi van der Meer 2002, 575-580.
} 
de pavajul subsolului. Această situație particulară s-a datorat modului în care a putut fi săpat subsolul camerei, respectiv al fundațiilor zidurilor portante, în stânca nativă. Astfel, o porțiune din acest zid, respectiv partea sa inferioară din subsol, a fost formată numai din stâncă tăiată vertical.

Se constată şi faptul că nivelul pavimentului din subsolul spaţiului B este mai ridicat cu 0,25 $0,27 \mathrm{~m}$ față de cel al spaţiilor contemporane A, $\mathrm{A}^{\prime}$ şi D. Diferența dintre cota pardoselii de la nivelul parterului și nivelul superior al crepidei păstrate în porțiunea estică a zidului $\mathrm{Z5}$, unde acesta se îngustează în elevaţie cu $5-7 \mathrm{~cm}$, corespunde sumei dintre înălţimea totală de cca $60 \mathrm{~cm}$ (pila cea mai înaltă descoperită in situ, formată din 7 cărămizi ${ }^{13}$, respectând regulile întâlnite la Vitruvius) și grosimea medie de cca $15 \mathrm{~cm}$ a pardoselii (suspensurae) ${ }^{14}$. Probabil, aceasta era cota medie de călcare la parterul întregii constructii în faza 2. După cum observam și în primul raport de cercetare arheologică $^{15}$, pilonii de susținere ai pardoselii au fost realizați din cărămizi pătrate cu dimensiuni de $17 \times 17 \times 6 \mathrm{~cm}$ şi $27 \times 27 \times 6,50 \mathrm{~cm}$ la bază şi în porțiunea superioară, legate cu un strat de mortar subţire de aproximativ $1 \mathrm{~cm}$. Pardoseala parterului era susţinută de cărămizi mari, pătrate, cu latura de $58 \mathrm{~cm}$ și grosimea de $7,50 \mathrm{~cm}$, dimensiuni care corespund interaxului dintre pile.

Începând de la nivelul de călcare al parterului, pereţii camerelor încălzite erau dublaţi cu placaj realizat din tegulae mammatae, în spatele cărora circula aerul cald. Fragmentele descoperite în timpul săpăturilor indică utilizarea mai multor tipuri de material ceramic de construcție de acest fel, înălţimea şi formele ,picioarelor” fiind variabile $(5-7,50 \mathrm{~cm})$.

Bazinul de apă rece a fost construit, după cum am amintit, în aceasta fază în camera I (dimensiuni interioare de $2,40 \times 3,15 / 3,20 \mathrm{~m}$ ) având ziduri groase de $0,65 \mathrm{~cm}$. Talpa fundaţiei zidului de nord, Z6, este mai coborâtă cu $0,20-0,25 \mathrm{~m}$ față de cota fundației zidului $Z 5$, surprinsă în extremitatea sudică, în dreptul canalului c2 (PI. IV/2, VIII/1). Baza bazinului a suferit modificări ale nivelului în două momente, cota sa inferioară fiind ridicată de două ori, cu câte $0,25 \mathrm{~m}$ cu ocazia unor reparaţii (Pl. VIII/2). Pereţii construcţiei au fost placaţi, cel puţin în prima fază de funcţionare a bazinului, cu un strat de cărămizi, groase de $6 \mathrm{~cm}$, puse pe cant şi acoperite cu tencuială hidraulică - opus signinum. Scurgerea apei din bazin se făcea pe latura de sud, printr-un canal cu traseu cotit (c2), care făcea legătura cu canalul c1, la ieşirea acestuia de sub/din zidul Z3. În această zonă, în umplutura canalului au fost identificate fragmente de tencuială pictată provenite de pe zidurile din apropiere. Fragmentele de tencuială pot fi grupate în două loturi ${ }^{16}$.

În faza 3 a edificiului E2, pe suprafaţa ocupată de construcţia termelor se înalţă un alt edificiu public cu o compartimentare diferită (PI. XI), dar preluând, parţial, traseul unor ziduri din vechea construcţie, respectiv zidurile perimetrale Z9, Z10 şi compartimentările Z2 şi Z8.

Limita nordică a noii construcții se deplasează cu 2,10-2,50 m spre nord faţă de limita băilor din faza 2 (Z6). Spre vest, Z5 (faza 2) este înlocuit de Z12, la o distanță de cca $0,20-0,30 \mathrm{~m}$ (PI. VII/3). Construirea zidului perimetral Z12 corespunde dezafectării bazinului de apă rece din camera I, acesta suprapunând traiectele demolate ale zidurilor Z6 (PI. VIII/3) și Z14.

Noua construcţie este divizată de un zid median $Z 4$, orientat $E-V$, conceput pe traseul zidului despărţitor dintre încăperile $\mathrm{A}$ şi $\mathrm{A}^{\prime}$ şi folosindu-l ca fundaţie. În spaţiul încăperii $\mathrm{D}$, talpa zidului median Z4 a fost dispusă peste pavimentul subsolului utilizat în fazele 1 și 2 (Pl. VI/2). Un nivel bine conturat a fost identificat parțial în două încăperi $D 1$ şi $\mathrm{A}^{\prime}$, în proximitatea intersecției zidului Z8 cu fața sudică a zidului Z4. Acesta este format dintr-un paviment de cocciopesto grossolano, cu suport din două straturi de piatră de râu, amenajat peste un strat de lut galben curat, de nivelare, care acoperea nivelul de dărâmătură al fazei a doua a edificiului. La limita superioară a stratului de pământ galben a fost observată o înșiruire de pietre de dimensiuni mici care are

\footnotetext{
${ }^{13}$ Tentea, Voişian 2003a, 449

${ }^{14}$ Marea majoritate a pilonilor de cărămidă aveau înălţimea de $0,60 \mathrm{~m}$ (2 picioare romane - Vitruvius V 10,5,6). Gazele erau evacuate prin spaţiul creat de sistemul roman de pereți falşi, prin utilizarea de tegulae mammatae. Deasupra

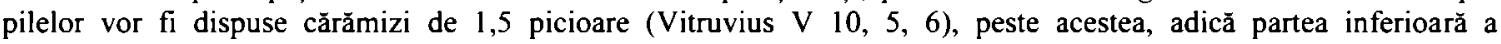
pavimentului (suspensura), va fi formată din cărămizi pătrate cu latura de două picioare.

${ }^{15}$ Tentea, Voişian 2003a, 449

${ }^{16}$ Patru fragmente de tencuială pictată au fost realizate în tehnica frescei. Pigmenţii utilizaţi sunt: albul de var (carbonat de calciu), negrul de cărbune şi pământul roşu. Tencuiala suport este albă, compactă, omogenă, având o grosime de 2 $\mathrm{mm}$, având în compoziţie var, praf fin de cărămidă (5\%) şi câlţi. Analiza tencuielii suport şi a pigmenţilor a fost realizată prin microchimie analitică de către Doina Boroş, în cadrul Laboratorului Zonal de Restaurare al Muzeul Naţional de Istorie a Transilvaniei, Sectorul Investigaţii Chimice (buletin de analiză 7/2002).
} 
aspectul unui paviment de piatră bătută în pământ $\left(\right.$ PI. VI/3, VII/1) ${ }^{17}$. Suntem de părere că acest strat nu reprezintă un pavaj, ci un nivel superficial, intermediar între stratul de pământ galben folosit pentru nivelarea dărâmăturii fazei 2 şi amenajarea substrucţiei din bolovani pentru cocciopesto grosolano, la rândul ei reprezentând substrucția unui paviment sau a unei podele.

Datorită faptului că modificările planimetrice ale clădirii (în faza 3) sunt foarte numeroase față de etapa constructivă precedentă, am fost înclinați să credem că baia a fost dezafectată, iar în cazul edificiului din ultima fază pare să fi fost vorba de o schimbare a destinației acestuia. Planimetria este schimbată considerabil, după cum se poate observa şi din plan (PI. XV), unele spații sunt dezafectate (bazinul din camera I), iar altele reconfigurate substanțial, cum ar fi întregul spațiu situat la nord de zidul $\mathrm{Z} 4$. Nu putem preciza destinația noii construcții şi nici legătura acesteia cu eventuale construcții aflate în proximitatea vestică. De asemenea, trebuie să precizăm că cele două altare dedicate lui Silvanus pot fi atribuite acestei faze de construcție exclusiv pe baza unor argumente logice. Pornind de la aceste descoperiri se poate doar sugera schimbarea destinației clădirii într-una cu o eventuală funcție cultică ${ }^{18}$.

Pentru o mai bună înțelegere a funcționării edificiului, am efectuat o sondare a zonei învecinate. În acest sens am deschis două secțiuni în interiorul platoului, în zona estică a acestuia, cu scopul de a stabili eventuale legături cu căi antice de acces sau de a identifica alte clădiri care sar fi putut afla în apropiere. Demersul nu s-a soldat cu descoperiri relevante. Datorită pantei accentuate din zona sudică nu am realizat o sondare a acestei porțiuni.

Așadar, zona în care am putut continua investigațiile a fost cea vestică. În acest spațiu, la aproximativ $13 \mathrm{~m}$ de edificiul E2, în caroul 17 al S8, a fost identificat un mormânt de incineraţie (PI. III). S-a păstrat doar partea inferioară a acestui complex, cu o adâncime de aproximativ $10 \mathrm{~cm}$. Mormântul era orientat aproximativ $\mathrm{N}-\mathrm{S}$, având dimensiunile de $1,10 \times 0,60 \mathrm{~m}$. Din inventarul funerar, foarte fragmentar, putem consemna: fragmente dintr-un opaiţ, dar și de la două vase globulare și trei turribula, două fragmente dintr-un vas de dimensiuni mai mari, un mâner din bronz provenit de la o cutie de lemn, o cheie de fier, precum şi câţiva pigmenţi de cărbune şi oase calcinate $^{19}$. Elementele de datare tipologice și contextuale nu pot oferi indicii asupra unei încadrări cronologice mai precise a complexului. Fiind vorba de o identificare în cadrul unei secțiuni de control la vest de clădirea amintită, nu putem stabili vreo conexiune între momentul depunerii defunctului și funcționarea vreunei faze a edificiului cercetat. Distanța dintre acest mormânt și aria funerară identificată în limita vestică a platoului în anul $2001^{20}$ este de $150 \mathrm{~m}$ în linie dreaptă, ambele descoperiri aflându-se la aceeași cotă de nivel. Este posibil ca mormântul identificat de noi să facă parte dintr-un grup de morminte distinct de cel din vestul platoului, nefiind însă exclus ca aceste complexe să fi făcut parte la un moment dat din aceeași arie funerară. De asemenea, în vecinătatea vestică a edificiului au fost descoperite câteva structuri aparent de natură antropică, care ar putea fi interpretate ca fiind ziduri, însă gradul lor de păstrare era foarte precar. Nu este exclus să fie vorba despre anexe ale clădirii E2 în ultima sa fază sau ruinele unei clădiri învecinate. În stadiul actual al cercetării zonei nu poate fi formulată o ipoteză concludentă în acest sens.

\section{ALTARELE VOTIVE}

În cursul cercetărilor au fost descoperite două altare votive dedicate lui Silvanus. Primul a fost descoperit în partea superioară a nivelului de demolare a edificiului E2, în proximitatea limitei

\footnotetext{
${ }^{17}$ Acest nivel a fost identificat în campania din anul 2001, pe profilul vestic al S25-26, între metri 1,50-3,50; vezi Tentea, Voișian 2003a, 461, fig. 7.

${ }^{18}$ Se cunosc și cazuri în care în inscripțiile care menționează unele lucrări din băi au fost dedicate unor divinități. De exemplu, altare pentru Fortuna au fost descoperite în tepidarium la bãile de la Chesters (RIB 1449) sau în apodyterium în băile de la Walldüm (CIL XIII 6592; Baatz 1978, 75, fig. Abb. 10). Vom aminti aici şi reprezentarea zeului Pan, divinitate care se confundă uneori cu Fanus sau Silvanus, pe un bloc paralelipipedic de calcar amplasat pe fațada băilor din Barzan (Charente-Maritime, în Gallia Aquitania) - Santrot 2003, 207-209.

${ }^{19}$ Tentea, Voișian 2003b, 280-282, nr. 163

${ }^{20}$ Rusu-Bolindeț et alii 2003, 389-390, 401, fig. 1
} 
vestice a acestuia (PI. III/A1 - dedicaţie pentru Silvanus Augustus), antrenat într-un nivel deranjat. Al doilea altar a fost identificat tot în poziţie secundară, într-un context reprezentând o intervenţie modernă, care a deranjat stratul de dărâmătură a zidurilor edificiului din camera B'. Poziția sa oblică indica o angrenare sau o alunecare a acestuia în cursul unei deranjări semnificative a stratului arheologic (PI. III/A2 - dedicație pentru Silvanus Domesticus).

Silvanus este un zeu cu o multitudine de atribute, care se confundă uneori cu cele ale lui Pan sau ale lui Fanus, cultul său oficiindu-se în mijlocul naturii. În scrierile autorilor clasici latini se regăsesc numeroase date referitoare la oficierea și aspectele cultului lui Silvanus. Date despre răspândirea cultului în Imperiu - cu excepția Romei și a Italiei - indică cea mai mare frecvență a atestārilor în Pannonia (cca 250), Dacia (cca 100), Dalmatia (cca 90) şi Galia Narbonensis (cca $65)^{21}$. În interpretarea acestei statistici trebuie avut în vedere faptul că numărul de atestări nu este raportat la intervalul cronologic în care au fost făcute aceste dedicații, ceea ce ar apropia foarte mult situația din Dacia de cea din Pannonia. La nordul Dunării, cultul zeului Silvanus a fost cel mai frecvent atestat în Dacia Superior. Mihai Bărbulescu considera că cei mai importanți factori care au contribuit la răspândirea cultului lui Silvanus în Dacia au fost minierii dalmatini, coloniştii din Pannonia şi chiar soldaţii trupelor de mauri ${ }^{22}$. Cel mai frecvent epitet al Silvanus, atât în Dacia (59), cât și în Pannonia este Domesticus. Acest epitet poate fi interpretat ca o invocare a protecției divine pentru locul în care respectivii indivizi își desfăşurau activitatea ${ }^{23}$. În studiile privitoare la „cultul imperial” discuția asupra divinităților care primesc epitetul „Augustus” sau „Augusta” a devenit un loc comun ${ }^{24}$. Acest epitet indicã asocierea divinității cu persoana împăratului, presupunând o transferare a puterilor zeului asupra împaratului și a familiei sale. Prin aceste practici, persoana care făcea dedicaţia îşi exprima loialitatea faţă de împărat, fapt care nu coincidea cu identificarea acestuia din urmă cu divinitatea adorată. Actul în sine nu poate fi interpretat ca o manifestare aparținând cultului imperial ${ }^{25}$.

Numele dedicantului celei de-a doua inscripții, Helius, scris în forma HIILIVS, este de proveniență greacă - Helios. Numele Helius apare în patru inscripții de la Salona (Dalmatia) ${ }^{26}$. Același nume a fost întâlnit în câteva inscripții din zona dobrogeană a provinciei Moesia inferior ${ }^{27}$. Un libert, M. Herennius Helius a fost atestat pe o inscripție de la Cybalae (Vinkovci) în Pannonia Inferior $^{28}$. Din aceste câteva exemple prezentate se poate observa frecvența numelui în rândul peregrinilor, fapt care poate fi un indicator şi pentru originea personajului nostru. $\mathrm{Nu}$ este exclus însã ca acesta să fi fost sclav.

${ }^{21}$ Dorcey 1992, $161 \mathrm{sqq}$

${ }^{22}$ Distribuţia atestărilor epigrafice ale cultului indică următoarea situație: Apulum (32), Micia (21), Alburnus Maior (11), Napoca (7), Ampelum (6), Ulpia Traiana Sarmizegetusa (5), Potaissa (5), Porolissum (4), Tibiscum (1) - Pribac 2006, 55-56, 270-275; Bărbulescu 2003, 256-257; Bărbulescu 2009, 70.

Din studiul statistic realizat de Sorin Pribac (vezi nota anterioară) reiese următoarea situaţie: meşteşugari (35), negustori (32), militari (23), notabilități (12), ceea ce nu conduce spre ideea adorării acestei divinităţi în special de către persoane de condiție modestă.

Întrucât în cazul unei mari părţi din dedicaţii textul inscripţiilor este destul de lacunar, nu s-au putut formula concluzii semnificative privitoare la originea sau statutul social al dedicanţilor.

${ }^{23}$ Clasificarea cultelor din zona minieră, în funcţie de legăturile cu activitatea minieră propriu-zisă, se împart în trei grupe: divinităţi ale naturii (Liber, Silvanus, Diana, Ceres), ale adâncurilor (Dis Pater, Terra Mater, Orcia, Aeracura) și zei care patronează activitățile miniere sau officinae metalurgice (Hercule, Vulcanus, Neptun), vezi Dušanić 2004, 264.

${ }^{24}$ Fishwick 1991, 446-454

${ }^{25}$ Fishwick 1991, 446-448, 453; Gradel 2002, 104-105. Astfel, potrivit lui Ittai Gradel, venerarea împăratului este una onorifică, fără a putea fi încadrată exclusiv în sfera politicului sau a religiosului. Puterea absolută a împăratului inducea doar asimilarea sa cu un zeu. Manifestările cultului imperial se regăsesc, potrivit aceluiași autor, în sfera privată, mai ales la nivelul celor cu statut social inferior, liberţi sau sclavi (Gradel 2002, 1-27). Pentru împăratul în viaţă exista cel puţin teoretic un cult indirect, chiar dacă nu sunt cunoscute ex voto-uri dedicate acestuia. Pentru o scurtă trecere în revistă a istoriografiei cultului imperial în Dacia, vezi Bulzan 2008, 9-21. Motivul dedicaţiei nu este consemnat explicit, formulele VSLM sau VSLL indică vag un contract anterior între dedicant și divinitate.

${ }^{26}$ Helius, libert sau sclav: domino / b(ene) m(erenti) p(osuit) (CIL III 2045), Iulius Helius (CIL III 2391), Q(uintus) Aernius Helius (CIL III 12917), Q. Cloelius Helius, dedicație pentru Silvanus Augustus (CIL III 14677= AÉ 1900, 00138)

${ }^{27}$ Trei inscripții sunt puse în legătură cu acelaşi personaj, probabil scrib, două inscripții de la Capidava (descoperite la Crucea, jud. Constanţa) (CIL III 14214, 20 = ISM V, 29; CIL III $13737=$ ISM V, 20) şi una de la Ulmetum (Pantelimon) (ISM V 73 = AÉ 1912, $300=$ AÉ 1922, 64): Cocc(eius) (H)elius / scripsit! O altă inscripţie atesta un Helius, domo Amurio (ISM V 234, Topolog).

${ }^{28}$ CIL III $9966=$ CIL III 13360 
Ştampilele cu marca legiunii XIII Gemina descoperite în edificiul E2 se încadrează cu precădere în tipurile databile în prima parte a secolului al II-lea p. Chr. Cea mai însemnată cantitate de material ceramic de construcție ștampilat de acest fel a fost descoperită în principal la Apulum, dar şi pe teritoriul provinciei ${ }^{29}$. O situație aparte o reprezintă ştampila $\mathrm{P}$ CLo, identificată pe o cărămidă descoperită în edificiul E1, marcată, de asemenea, cu o ştampilă a legiunii XIII Gemina ${ }^{30}$. Analogiile acestei ştampile se găsesc doar la Apulum, în zona pretoriului guvernatorului (imprimate pe trei țigle pentru acoperiş̧) ${ }^{31}$. Un fragment de tegula mammata, descoperit în anul 2002 în clădirea E2 este marcat cu acelaşi tip de ştampilă (PI. XIX/6). Astfel, această semnalare stabilește un nou element de legătură între cele două edificii prevăzute cu hypocaustum de pe Dealul Carpeni.

Vasile Moga era de părere că materialul ceramic de construcție, marcat cu însemnele legiunii XIII Gemina, a fost produs la Apulum, fiind ulterior distribuit de către vexilaţiile acesteia ${ }^{32}$. Acest fapt a fost confirmat şi de rezultatele analizelor mineralogice efectuate pe lotul de material ştampilat de la Roșia Montană, comparativ cu loturi similare de la Apulum $^{33}$. Nu există elemente de datare în funcţie de contextele arheologice care să poată fi corelate cu datarea tipologică a ştampilelor. Astfel, datarea tipologică a acestor artefacte nu poate constitui în sine decât un indiciu asupra datării edificiilor E1 şi a primei faze a clădirii $\mathrm{E} 2$, cu atât mai mult cu cât fragmentele acestor piese au fost descoperite aproape exclusiv în poziţie secundară ${ }^{34}$.

În cursul cercetărilor din cele trei campanii arheologice referitoare la edificiul E2 au fost identificate 13 monede. Două dintre acestea au fost publicate în raportul primei campanii ${ }^{35}$. Acestea provin din contexte aparținând ultimelor două faze de folosire și demolare ale edificiului.

Cea mai mare frecvenţă monetară poate fi observată pentru monedele emise în perioada 117-138 - Hadrian - (5 monede) comparativ cu celelalte „grupuri”: flavieni (3 piese), Traian (2), Antoninus Pius (2). Cea mai târzie piesă, ca dată de emisiune, este moneda cu efigia Iuliei Mamaea, mama împăratului Severus Alexander (222-235 p. Chr.). Această frecvență a monedelor, indică o activitate mai intensă începând probabil cu domnia lui Traian, continuând cu Hadrian şi Antoninus Pius. Monedele flaviene pot fi interpretate ca fiind rămase în circulaţie.

Se poate observa un hiatus între majoritatea monedelor şi cea emisă în timpul lui Severus Alexander, fapt care poate fi pus în legătură cu perioada turbulentă începută odată cu războaiele marcomanice, moment care va fi determinat scăderea considerabilă a activităților miniere din arealul Roșiei Montane.

Monedele descoperite sunt din bronz: 3 sesterți, 2 dupondii, 4 ași, una provincială, două neidentificabile. Singura monedă care oficial ar aparţine categoriei monedelor de argint este un denar subaerat (nr. cat. 10). Monedele fac parte din categoria celor de valoare mică sau medie în cadrul sistemului monetar roman. Din această cauză, asemenea monede sunt cele mai numeroase în circulaţie, având așadar şansele cele mai mari de a fi pierdute ${ }^{36}$.

\footnotetext{
${ }^{29}$ Szilágyi 1946, 42-44, pl. IlI-IV; Moga 1985, 51; Băluţă 1997, 135; Piso 2000, 221

${ }^{30}$ Țentea 2003, 264, fig. 2/4a, b

${ }^{31}$ IDR III/6 85 = Băluţă 1997, p. 142, nr. VII = Băluţă 2000, 371

${ }^{32}$ Moga 1985, 46

${ }^{33}$ Ionescu, Ghergari, Țentea 2006, 413-436. La data publicării acestor ştampile de pe Dealul Carpeni, sub rezerva rezultatelor analizelor mineralogice, eram de părere că prezenţa materialului tegular cu ștampilele legiunii XIII Gemina atestă stał̧ionarea unor (unei) vexilaţii legionare în zona Alburnus Maior cel puţin pe durata fabricării materialului tegular și, eventual, a construirii unor edificii în locul amintit, vezi Țentea 2003, 257, nota 40.

${ }^{34}$ Excepţia o reprezintă o ștampilă pl. XIX/4.

${ }^{35}$ Țentea, Voişian 2003a, 451, nr. 1,2

${ }^{36}$ Folosim şi acest prilej pentru a-i mulţumi colegului Cristian Găzdac pentru sprijinul amabil acordat pentru prelucrarea și interpretarea monedelor.
} 
Baia este un simbol al civilizaţiei romane, ea putând fi încadrată între serviciu public şi o instituţie în sine. În abordarea noastră ne-am concentrat asupra unei prezentări cât mai detaliate a săpăturii şi a diverselor situaţii arheologice existente, încercând să lămurim cât mai multe aspecte relevante privitoare la funcţionalitatea edificiilor şi la modul de funcţionare a unor instalaţii. După finalizarea cercetărilor de teren şi procesarea grafică a documentaţiei de săpătură astfel rezultate, sarcina cea mai dificila a fost încercarea de a identifica funcția/funcționalitatea fiecărei săli/camere, întrucât o parte importantă a clădirii, altfel spus structurile constructive, s-a păstrat sub nivelul antic de călcare.

Analogiile sunt o bună sursă de stabilire a funcţiei camerelor, însă exemplele avute în vedere au trecut la rândul lor printr-un proces similar, motiv pentru care am optat pentru analiza comparativă cu mult mai multe analogii, chiar dacă unele sunt doar analogii parţiale $\mathrm{e}^{37}$.

Modificările constructive efectuate în anumite spații au putut implica inclusiv modificarea funcţiei sălii respective. Ca reper am avut în vedere observaţiile cercetătorilor moderni privind obligativitatea refacerii subsolului la un interval relativ mic în comparație cu celelalte structuri, pilonii de cărămidă fiind supuși permanent interacțiunii cu aerul fierbinte.

În cazul oricărei băi publice era obligatorie existenţa unui traseu de îmbăiere, care conţine cel puțin succesiunea $F$ (rigidarium) - T(epidarium) - C(aldarium), având ca fundament gruparea camerelor încălzite în jurul unui praefurnium. Astfel combustibilul putea fi utilizat cu eficienţă $\operatorname{maximă}^{38}$.

Edificiul E2 face parte aşadar din categoria băilor de dimensiuni mici (balnea). Aceasta era menită să deservească un număr relativ redus de persoane.

CONCLUZII

Topografia arheologică a Dealului Carpeni indică existenţa unor elemente de habitat, a unor posibile edificii de cult (?) sau atestări ale unor collegia (?), precum și a celor două edificii cu caracter public (E1 și E2). Stabilirea unor relaţii cronologice sau funcţionale între cele trei puncte cercetate arheologic în cuprinsul Dealului Carpeni este greu de realizat. Dificultăţile constau în faptul că, pe de-o parte, în actualul stadiu al cercetărilor, nu deţinem date privitoare la reţeaua de drumuri din zonă, iar pe de altă parte, configurația terenului din zona estică a dealului a fost modificată de depunerile de steril rezultate din activităţi miniere moderne, fapt care a îngreunat cercetarea de teren.

Așadar, putem vorbi de o relaţionare a edificiilor E1 şi E2 întrucât ambele au fost prevăzute cu instalaţii de hypocaustum, construite din material ceramic de construcție marcat cu ștampila legiunii XIII Gemina, tehnica de construcţie a zidurilor fiind - de asemenea - similară (ziduri legate cu mortar şi tencuite). Se poate argumenta o contemporaneitate, cel puţin parțială, a clădirilor, durata lor de funcţionare fiind însă diferită. Edificiul E1 a avut o singură fază de construcție și funcționare, neputând fi sesizate - din punct de vedere arheologic - reparaţii semnificative. Avându-se în vedere durata medie de funcţionare a unei instalaţii de hypocaustum, de până la 25-30 ani şi incluzând unele eventuale reparații minore, putem conchide că această clădire a funcţionat destul de puțin timp. În cazul edificiului E2, însă, au putut fi sesizate faze şi amenajări care indică o durată de folosire mult mai mare. Vom reaminti aici că două variante identice de ştampile se regăsesc pe materialul ceramic de construcție descoperit în ambele edificii ${ }^{39}$. Din punct de vedere tipologic avem de-a face cu două băi (balnea), care au funcționat într-o zonă frecventată atât de personal administrativ, dar şi de comunităţi de arendași.

\footnotetext{
${ }^{37}$ Pentru o scurtă trecere în revistă a listei actualizate a descoperirilor din Dacia, vezi Țentea 2010, 455-458.

${ }^{38}$ Băile erau amplasate în locuri cât mai călduroase, fiind orientate cu spatele spre nord. [...] Băile vor avea ferestrele indreptate spre vestul de iarnă sau, in cazul in care conformafia terenului nu permite, orientarea acestora va fi spre sud, deoarece perioada cea mai obişnuită pentru baie este de la amiază până seara [...] (Vitruvius V 10, 1).

${ }^{39}$ Pentru ștampilele legiunii, vezi comparativ Țentea 2003, 264-265, fig. 2-3. Pentru ștampila PCLo: E1 - Țentea 2003, 264, fig. 2/4b, iar pentru E2, pl. XIX/6.
} 
Cea mai mare frecvenţă monetară, pentru lotul descoperit în băile E2, se încadrează în perioada 117-138, iar după un interval considerabil de timp este semnalată o descoperire din timpul lui Severus Alexander. Acest fapt poate fi pus în legătură cu scăderea considerabilă a activităților miniere din arealul Roșiei Montane începând cu mijlocul secolului al II-lea p. Chr.

\section{CATALOG}

\section{ALTARE VOTIVE (PI. XVI-XVII)}

1. Altar de calcar, rupt în partea stângă a aticului, în profunzime până dincolo de conturul reprezentat de foculus. Dimensiuni: $53 \times 24,5 \times 20,50 \mathrm{~cm}$ (la bază). Altarul are o profilatură simplă, format din trei praguri, atât la atic, cât şi la bază. Câmpul epigrafic are dimensiunile de $23 \times 21 \mathrm{~cm}$. $\mathrm{H}$ litere inegale între 4,50-5 cm, dimensiunile literei $O$ fiind de aproximativ $2 \mathrm{~cm}$.

R. 1-3, A fără bara mediană

Roşia Montană 2002, E2, poziţie secundară PI. III.1, XVI

\author{
Silly[a]no \\ Augusto \\ sacrum \\ $v$ (otum) s(olvit) l(ibens) l(aetus) vel \\ $v$ (otum) s(olverunt) l(ibentes) l(aeti).
}

2. Altar de calcar, rupt în partea stângă a aticului, în profunzime până în apropierea de foculus. Dimensiuni: $55 \times 25,50 \times 18 \mathrm{~cm}$ (la bază). Altarul are o profilatură simplă, formată din trei praguri, atât la atic, cât şi la bază. Câmpul epigrafic are dimensiunile de $24 \times 25,50 \mathrm{~cm}$. Literele sunt inegale, având înălțimea cuprinsă între $4,50-5 \mathrm{~cm}$, dimensiunile literei $O$ fiind de aproximativ $2 \mathrm{~cm}$.

R. 1-2, O mai mic decât restul literelor; R. 3 E redat sub forma a două haste paralele.

Roşia Montană 2002, E2, poziţie secundară PI. III.2, XVII

Silvano
Domesti(co)
Helius
v(otum) s(olvit) l(ibens) m(erito).

STAMPILE (PI. XIX)

1. Ștampilă întreagă; $L=11,30 \times 3,40 \mathrm{~cm}$; text „LEG XIII”. Tip. LEG XIII

RM 2002, E2, S 004, nivelul superior al dărâmăturii din praefurnium. Dunga oblică este dată de o remodelare a cărămizii după ștampilare. / gros = $5,50 \mathrm{~cm}$; CAR(E2) nr. 9. PI. XIX/1

2. Ştampilă fragmentară; $11,20 \times 3,60 \mathrm{~cm}$; text „LEG XIII”. Tip. LEG XIII
RM 2003, E2, poziţie secundară; CAR(E2) nr. 14.

\section{PI. XIX/2}

3. Ştampilă fragmentară; $5,80 \times 3,60 \mathrm{~cm}$, text „LEC”. Tip. LEG XIII

RM 2002, E2, Z5 CAR(E2) nr. 10. PI. XIX/3

4. Ștampilă fragmentară; $6,10 \times 3,50 \mathrm{~cm}$ text „LEG”. Tip. LEG XIII

RM 2002, E2 / S 27 - praefurnium (in situ) CAR(E2) 11. Pl. XIX/4

5. Ștampilă fragmentară; $6,02 \times 3,40 \mathrm{~cm}$; text „,G XIII". Tip. LEG XIII

RM 2003, E2 , poziţie secundară; CAR(E2) nr. 13. PI. XIX/5

6. Ștampilă fragmentară; $h=3,50 \times 3,30 \mathrm{~cm} /$ gros $=3 \mathrm{~cm}$; text "L o(d?)". Tip. P C L o(d?)

Roșia Montană 2002, E2, S 002, tegula mammata, poziție secundară; CAR(E2) nr. 12. Pl. XIX/6

\section{CATALOGUL MONEDELOR (PI. XVIII)}

\section{VESPASIANVS / TITVS}

1. Sesterţ; AE; $17,90 \mathrm{~g} ; 30,50 \mathrm{~mm}$.

Avers: Legenda ştearsă; cap spre dreapta.

Revers: Ilizibil.

Roşia Montană 2003, CAR(E2)X8. PI. XVIII/1

\section{DOMITIANVS}

2. Sesterț AE; $19,40 \mathrm{~g} ; 32,30 \mathrm{~mm}$.

Avers: Legenda ştearsă; cap spre dreapta.

Revers: Ilizibil.

Roşia Montană 2003, CAR(E2)X10. PI. XVIII/2

3. Bronz, posibil provincial; $3,90 \mathrm{~g} ; 23,30 \mathrm{~mm}$.

Avers: ...[C?]ENS...; cap spre dreapta.

Revers: corodat

Roșia Montană 2003, CAR(E2)X9. PI. XVIII/3

\section{TRAIANVS}

4. Dupondius; AE; $\downarrow ; 11,10 \mathrm{~g} ; 26 \times 25 \mathrm{~mm}$. Avers: Legenda ilizibilă [imp caes ner traiano optimo aug ger dac parthico $\mathrm{p} m$ tr $\mathrm{p}$ cos vi $\mathrm{p} p$ ], bust drapat, radiat, spre dreapta.

Revers: [senatus populu]SQV[e romanus]; în exergă: [s c]; Traian între două trofee.

RIC II, p. 292, nr. 676, Roma 114-117 p. Chr. Tentea, Voişian 2003a, 451. nr. 1; Roşia Montană 2001, CAR(E2)1. PI. XVIII/4 
5. Sesterț AE; $\downarrow ; 20,20 \mathrm{~g} ; 31,20 \mathrm{~mm}$.

Avers: Legenda ilizibilă [imp caes nervae traiano aug ger dac $p \mathrm{~m}$ tr $\mathrm{p} \cos \mathrm{v} p \mathrm{p}$ ]; cap laureat spre dreapta.

Revers: Legenda ilizibilă [s p q r optimo principi / s - ] C; Spes, mergând spre stânga, ținând o floare. RIC II, p. 281, nr. 519, Roma, 103-111 p. Chr. Roşia Montană 2002, CAR(E2)X5. PI. XVIII/5

\section{HADRIANVS}

6. Dupondius; Axa: 6; D: $26,70 \times 25,10 \mathrm{~mm}$; G: 11,70 gr.

Avers: Legenda ilizibilă, dar continuă [imp caesar traianus aug $p \mathrm{~m}$ tr $\mathrm{p}$ cos iii], bust radiat spre dreapta, posibil drapat pe umărul stâng.

Revers: [moneta au]GVSTI; în câmp: S - C; Moneta, stând spre stânga, ţinând balanța şi comul abundenței.

RIC II, p. 417, nr. 600(a/b), Roma, 119-121 p.Chr. Roșia Montană 2002, CAR(E2)X3. PI. XVIII/6

7. As; AE; $6,10 \mathrm{~g} ; 27,10 \times 24,30 \mathrm{~mm}$.

Avers: Legenda ilizibilă dar continuă [imp caesar traian(us) aug/...]; cap laureat spre dreapta.

Revers: putemic corodat.

RIC II -, Roma, 119-121 p. Chr.

Roşia Montană 2002, CAR(E2)X4. PI. XVIII/7

8. As; AE; $\downarrow ; 8,70 \mathrm{~g} ; 25,10 \mathrm{~mm}$.

Avers: Legenda ilizibilă [hadrianus augustus]; cap laureat spre dreapta.

Revers: S[alus augusti] [s] - C; în exergă: COS II[i]; Salus spre stânga, ţinând un sceptru, hrănind şarpele încolăcit pe un altar.

RIC II, p. 427, nr. 678, Roma 125-128 p. Chr.

Roșia Montană 2003, CAR(E2)X7. PI. XVIII/8

9. As; $\mathrm{AE} ; \downarrow ; 9,30 \mathrm{~g} ; 27,30 \times 24,90 \mathrm{~mm}$.

Avers: Legenda ilizibilă; cap spre dreapta.

Revers: Legenda ilizibilă; siluetă spre stânga.

Roşia Montană 2003, CAR(E2)X6. PI. XVIII/9

\section{HADRIANVS: Lucius Aelius Caesar}

10. Denar fourré; AE argintat; $\downarrow ; 2,00 \mathrm{~g} ; 18 \mathrm{~mm}$; fragmentar.

Avers: [l aelius] - CAE[sar]; cap spre dreapta.

Revers: [tr pot c]OS II; în exergă: CONCOR[d];

Concordia şezând spre stânga, ţinând patera în mâna dreaptă şi cotul stâng rezemat pe comul abundenței.

Cf. RIC II, p. 392, nr. 436, Roma, 137 p. Chr.

Tentea, Voişian 2003a, 451. nr. 2; Roşia Montanã 2001, CAR(E2)2. PI. XVIII/10

TYR (SYRIA)

EMISIUNE PSEUDO-AUTONOMĀ

11. AE; $\pi ; 8.55 \mathrm{~g} ; 21,70 \times 20 \mathrm{~mm}$.

Avers: bustul lui Tyche, drapat, purtând voal spre dreapta; la stânga, o frunză de palmier.

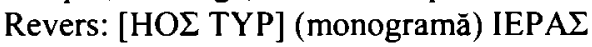

MHTPOПO/ $\mathrm{E} \Omega \Sigma$, Vas spre stânga.

Cf. RPC IV, 6815, 138-161 p. Chr.

Sub podeaua fazei a treia de piatră

Roşia Montană 2002, CAR(E2)X12. PI. XVIII/11

\section{ANTONINUS PIUS}

12. As; AE; $25 \times 25,5 \mathrm{~mm}$.

Avers: ANTONINVS - AVG PIVS P P; cap laureat spre dreapta.

Revers: [tr p]OT - [c]O[s iii]; S - C; Clementia spre stânga, ţinând patera şi sceptrul.

RIC III, 699, Roma, 140-144 p. Chr.

Roşia Montană 2003, CAR(E2)X13. PI. XVIII/12

SEVERVS ALEXANDER: IULIA MAMAEA?

13. $\mathrm{AE} ; \downarrow$ ?; $5.6 \mathrm{~g} ; 21 \mathrm{~mm}$.

Avers: cap spre dreapta.

Revers: Incert.

Monetărie provincială? 222-235 p. Chr.

Roşia Montană 2003, CAR(E2)X11. PI. XVIII/13

BIBLIOGRAFIE

Albumus Maior I

Baatz 1978

Băluță 1997

Bāluță 2000

Bărbulescu 2009
Alburnus Maior I (ed. P. Damian), București, 2003

D. Baatz (Mit Beiträgen von H.-J. Hundt, A. Krug, H. Schubert und H.-G. Simon), Das Badegebäude des Limeskastells Walldüm (Odenwaldkreis), SJ (Saalburg Jahrbuch, Bericht des Saalburg Museum, Mainz) 35, p. 61-107

Cl. L. Băluţă, Tipuri de ștampile tegulare militare inedite descoperite la Apulum. Il. Ştampile fără antroponim, Apulum, 34, 1997, p. 133-168

Claudia Băluţă. Tipuri de ștampile tegulare inedite descoperite recent la Apulum. Apulum, 37, 2000, p. 369-378

M. Bărbulescu, Africa e Dacia. Gli infussi africani nella Dacia, Africa romana. Atti del X convegno di studio, Oristano, II-13 dicembre 1992 (ed. 
Bărbulescu 2003

Bota, Tentea, Voişian 2003

Bulzan 2008

Damian, Borș 2007-2008

Dorcey 1992

Dušanić 2004

Pribac 2006

Fishwick 1991

Gradel 2002

Ionescu, Ghergari, Țentea 2006

van der Meer 2002

Moga 1985

Piso 2000

RIB

Rusu-Bolindeţ et alii 2003

Santrot 2003

Sântimbreanu 1989

Szilágyi 1946

Țentea 2003

Țentea 2009

Țentea 2010

Tentea, Voişian 2003a

Tentea, Voişian 2003b
A. Mastino, Paola Ruggeri), Sassari 1994, 1319-1338 = Signum originis. Religie, arta și societate in Dacia Romană, București, 2009, p. 61-76

M. Bărbulescu, Interferențe spirituale in Dacia romană, Cluj-Napoca, $2003^{2}$

E. Bota, O. Tentea, V. Voișian, Edificiul public din punctul Tomuș (E 1), în Alburnus Maior I, p. 433-446

S. Bulzan, Repere istoriografice ale cultului imperial în Dacia, în G. Moisa (ed.), Studii de istoriografie românească, Cluj-Napoca 2008, p. 9-21

P. Damian, Corina Borş, Consideraţii privind managementul arheologic în contextul proiectului minier Roșia Montană .Programul Naţional de Cercetare „Alburnus Maior” (2001-2006), CA, 14-15, 2007-2008, p. 481558

P. Dorcey, The Cult of Silvanus. A Study in Roman Folk Religion, Columbia Studies in the Classical Tradition 20, Leiden/New York/Cologne 1992

S. Dušanić, Roman mining in Illyricum: historical aspects, în Dall'Adriatico al Danubio: l'Illirico nell'età greca e romana: atti del convegno internazionale, Cividale del Friuli, 25-27 settembre 2003 (a cura di G. Urso), Pisa 2004, p. 247-270

S. Pribac, Aspecte sociale ale viefii spirituale din Dacia romană, cu privire specială asupra cultelor greco-romane, Timişoara, 2006

D. Fishwick, The Imperial Cult in the Latin West: Studies in the Ruller Cult of Western Provinces of the Roman Empire, II, 1, Leiden, 1991

I. Gradel, Emperor Worship and Roman Religion, Oxford, 2002

Corina Ionescu, Lucreția Ghergari, O. Țentea, Interdisciplinary (mineralogical-geological-archaeological) Study on the Tegular Material belonging to the Legion XIII Gemina from Alburnus Maior (Roșia Montană) and Apulum (Alba Iulia): possible Raw Materials Sources, $C A, 13,2006$, p. 413-436

L. B. van der Meer, Travertine Comerstones in Ostia Antica: Odd Blocks, American Journal of Archaeology, 106, 4, 2002, p. 575-580

V. Moga, Din istoria militară a Daciei romane. Legiunea XIII Gemina, ClujNapoca, 1985

I. Piso, Les légions dans la province de Dacie, în Y. Le Bohec (ed.), Les légions de Rome sous le Haut-Empire. Actes du Congrès de Lyon (17-19 septembre 1998), Lyon, 2000, p. 205-225

R.G. Collingwood, R.P. Wright, The Roman Inscriptions of Britain, I, Inscriptions on Stone, Oxford, 1965

Viorica Rusu-Bolindeț, C.A. Roman, E. Bota, Adriana Isac, Adela Paki, F. Marcu, Monica Bodea, Forme de habitat în punctul Balea, în Alburnus Maior $I$, p. $389-431$

J. Santrot, Le Pan et la divinité ,astral" des thermes, în A. Bouet, Les thermes privés et publics en Gaule narbonnaise, Collection de l'Ecole Française de Rome - 320, Rome, 2003, p. 207-209

A. Sântimbreanu, Muzeul mineritului din Roşia Montană, București, 1989

J. Szilágyi, A Dáciai erödrendszer helyörségei és a katonai téglabélyegek (Die Besatzungen des Verteidigungssystems von Dazien und ihre Ziegelstempel), Dissertationes Pannanonicae II. 21, Budapest, 1946

O. Țentea, Legion XIII Gemina and Alburnus Maior, Apulum, 40, 2003, p. 253-265

O. Țentea, On the Defence of Auraria Daciae, în O. Tentea, I. C. Opriş (eds.), Near and Beyond the Roman frontier. Proceedings of a Colloquium held at Târgovişte in October 2008, București, 2009, p. 371-381

O. Țentea, Balinea in Dacia, în H. Pop, I. Bejinariu, Sanda Băcueţ-Crișan, D. Băcueț-Crișan (eds.), Identităfi culturale locale și regionale in context european. Studii de arheologie şi antropologie istorică. In memoriam Alexandri V. Matei, Cluj-Napoca, 2010, p. 455-458

O. Tentea, V. Voișian, Edificiul public din punctul Bisericuță (E2), în Alburnus Maior I, p. 447-467

O. Tentea, V. Voişian, Roşia Montană, com. Roşia Montană, jud. Alba [Alburnus Maior]. „Bisericuţă” (Edificiul E2) - 2001-2003, CCA, 2003, p. 280-282, nr. 163 
Wollmann 1979

Wollmann 1985-1986

Wollmann 1996

Vitruvius
V. Wollmann, Monumente epigrafice și sculpturale din regiunea minieră Alburnus Maior - Ampelum, Sargetia, 14, 1979, p. 190-202

V. Wollmann, Un lucus la Alburnus Maior, AIIA (Anuarul Institutului de Istorie şi Arheologie, Cluj-Napoca) 27, 1985-1986, p. 253-295

V. Wollmann, Mineritul metalifer, extragerea sării şi carierele de piatră în Dacia romană. Der Erzbergbau, die Salzgewinnung und die Steinbrüche im römischen Dakien, Bibliotheca Musei Napocensis XIII, Cluj-Napoca, 1996 Vitruvvii Pollionis, De Architectura, Libri X, Vitruviu, Despre arhitectură (trad. G.M. Cantacuzino, T. Costa, Gr. lonescu), Bucureşti, 1964

\section{LIST OF ILLUSTRATION}

Pl. I Carpeni Hill 1. Aerial photo. View from the South. Photo: François Didierjean (2004); 2. Ortophotomap ANCPI. Building E2 in the center of the image

Pl. II General layout of the archaeological excavations on the E2 edifice following the 2003 campaign (Drawing architect Anişoara Sion)

Pl. II 1. Layout of the archaeological excavation at the end of 2001 campaign (after Țentea, Voișian 2003a, 456 fig. 2); 2. Layout of the archaeological excavation in 2001 and the final layout made in 2003 (M1 - grave, A1, 2 - altars)

Pl. IV 1. General view from the West; in the background Câmic Massif; 2. General view of the northern side of edifice E2; in the lower part of the image the basin of room I and channel c2

PI. V 1-3. General view of the northern area of edifice E2; 4. The praefurnium zone (view from North); 5-7. Praefurnium (details)

Pl. VI 1. Z9, detail on the succession of the construction phases; 2 . Image illustrating the construction of wall Z4 (phase 3) above the floor of the previous phase; 3 . Room $A^{\prime}$, detail of the substruction of phase $3 ; 4$. Intersection of wall Z4 (phase 3) the path of wall Z 5 (phases 1-2) and the remake of it in phase 3 only in the southern zone (left side of the image)

PI. VII 1. Rooms $A^{\prime}$ și $D^{\prime}$ (stratigraphic details of the succession of phases 2 and 3); 2. Base of the sustaining pillar of the floor, made of limestone slabs; 3. Walls Z5 (phase 2, left) and Z 12 (phase 3, right)

PI. VIII Cold water basin in room I: 1. General view from south-west; 2. Repairs of the base of the basin (details); 3. the overlapping zone of wall Z6 (phase 2) by wall Z12 (phase 3, moment when the basin is no longer in use, detail)

Pl. IX 1. Sketch regarding the location of the "archaeological" interventions in the " 60 s (drawing engineer A. Sîntimbreanu); 2-4. Images of the consequences of one of the trenches made in the ' $60 \mathrm{~s}$ in the southern part of the building E2; 5 . destructions due to the interventions made in the ' 60 s in the western part of building E2

Pl. X Edifice E2, labels of the rooms, walls and the marking of the axis of the altimetry profiles $\mathrm{AA}^{\prime}$ and $E E^{\prime}$

Pl. XI The altimetry profiles $\mathrm{AA}^{\prime}$ and $E E^{\prime}$

Pl. XII 3D model of edifice E2: view from the North (1) and from the West (2)

PI. XIII Layout of phase 1

PI. XIV Layout of phase 2

Pl. XV Layout of phase 3

Pl. XVI Altar dedicated to Silvanus Domesticus (photo, drawing)

Pl. XVII Altar dedicated to Silvanus Augustus (photo, drawing)

Pl. XVIII The coins discovered during 2001-2003 excavations at edifice E2

Pl. XIX Brick stamps discovered during 2002-2003 excavations at edifice E2

OVIDIU ȚENTEA

Muzeul Naţional de Istorie a României ovidiu.tentea@gmail.com

VALENTIN VOIȘIAN

Muzeul Naţional de Istorie a Transilvaniei 


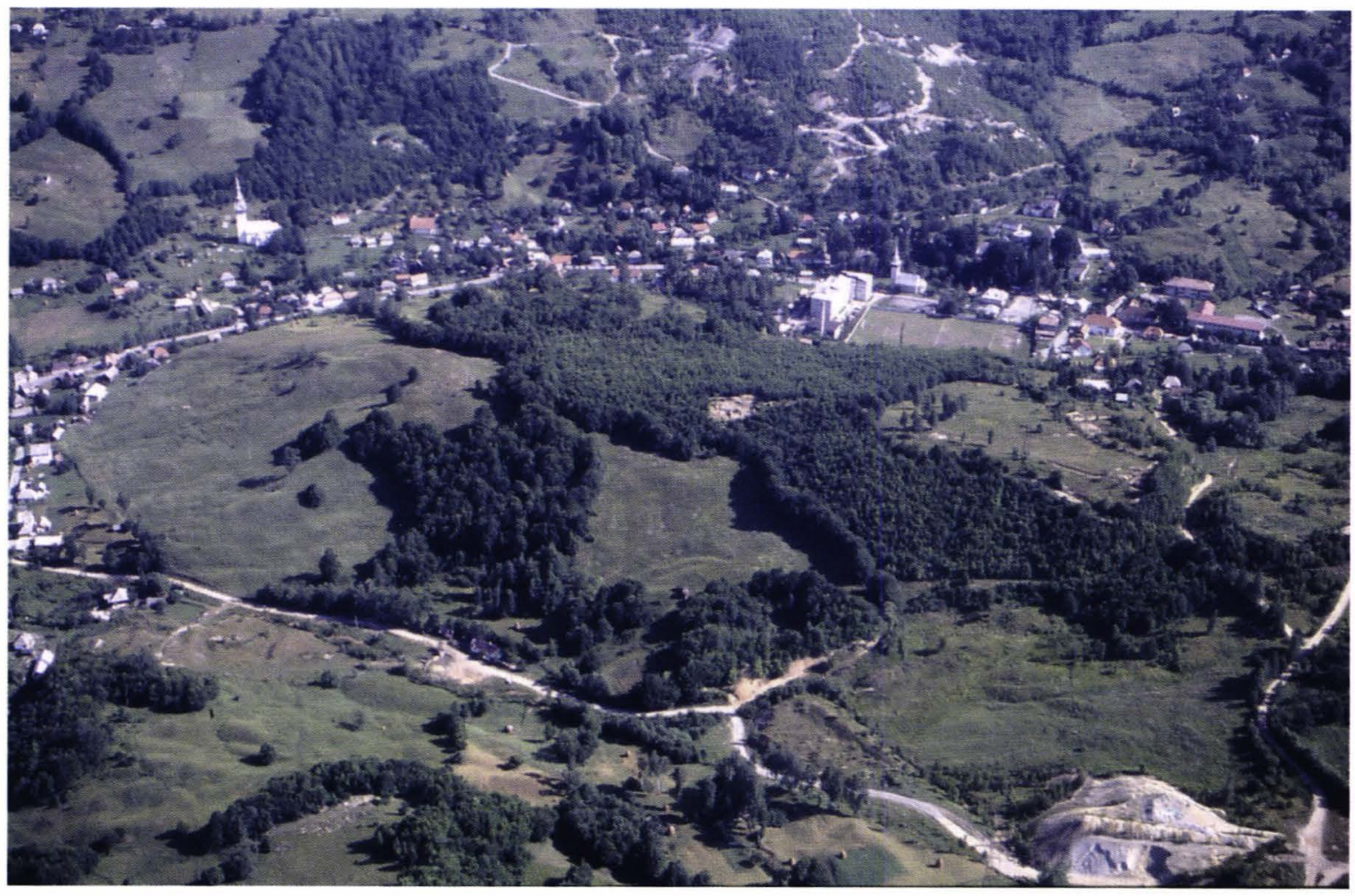

1.

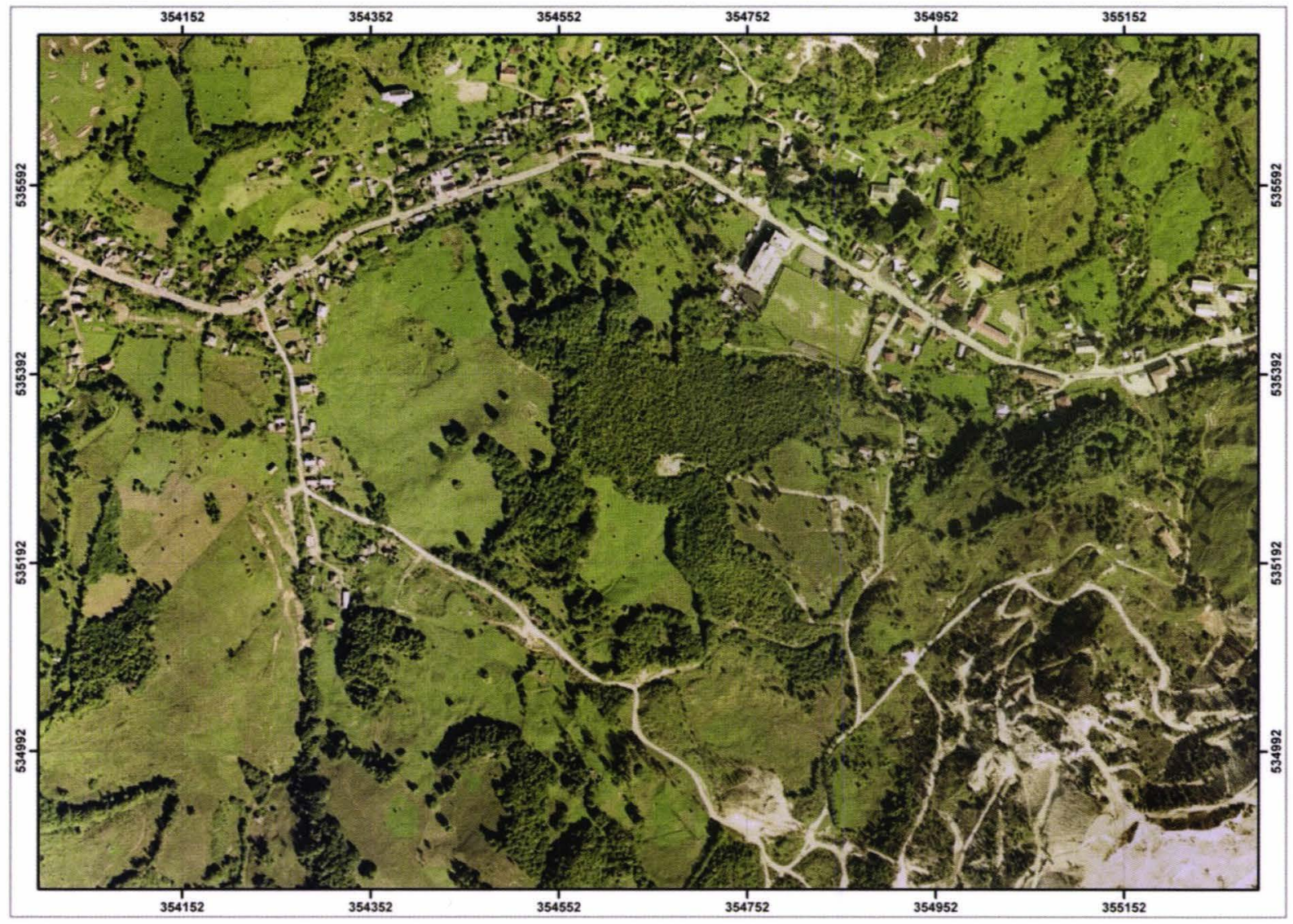

2.

Dealul Carpeni. 1. Fotografie aerienă. Vedere dinspre sud. Foto: François Didierjean (2004); 2. Ortofotoplan ANCPI. Clădirea E2 se distinge în centrul imaginilor 


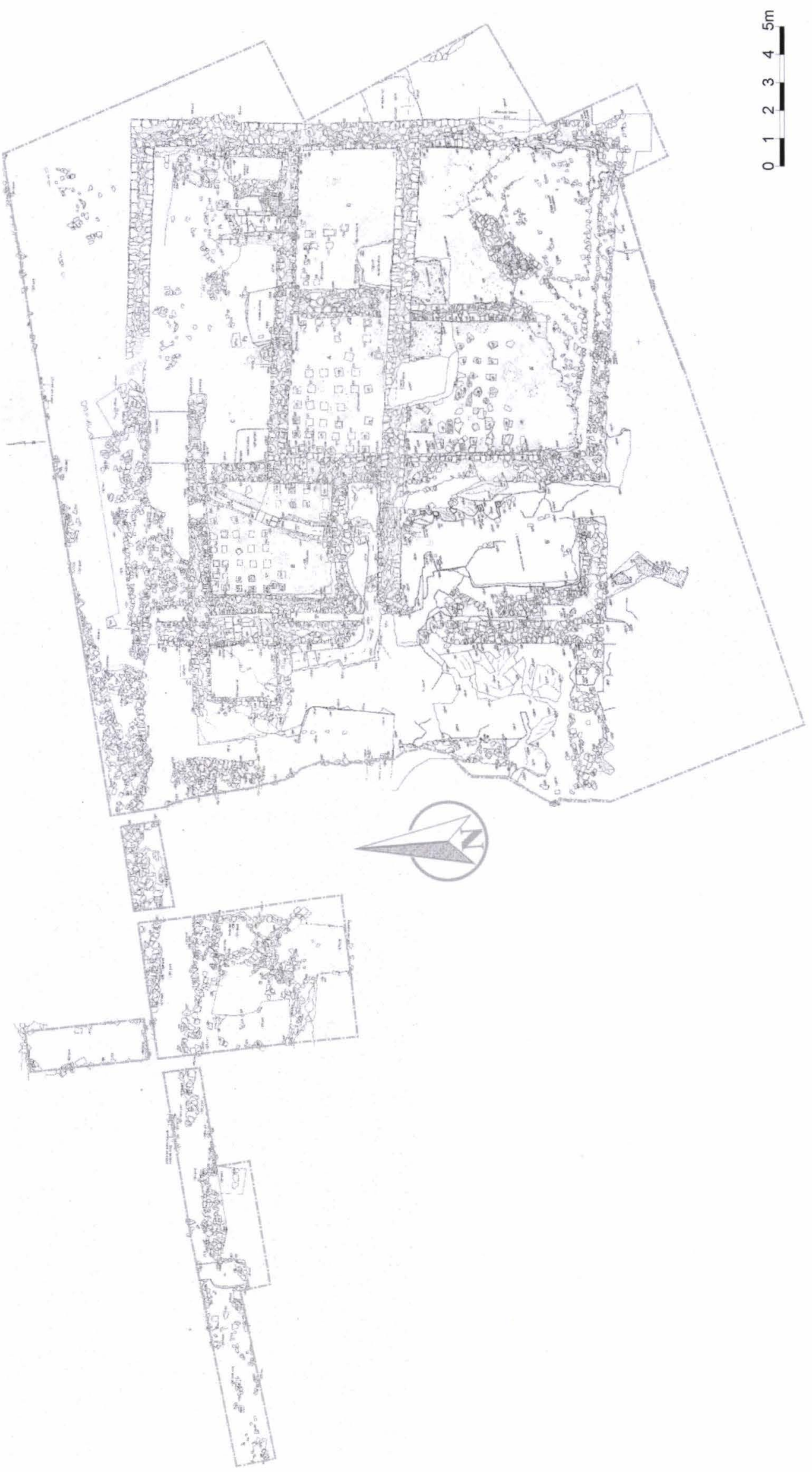

Planul general al cercetărilor arheologice privind edificiul E2 după campania din anul 2003 (desen arhitect Anișoara Sion)

\section{PI. II}




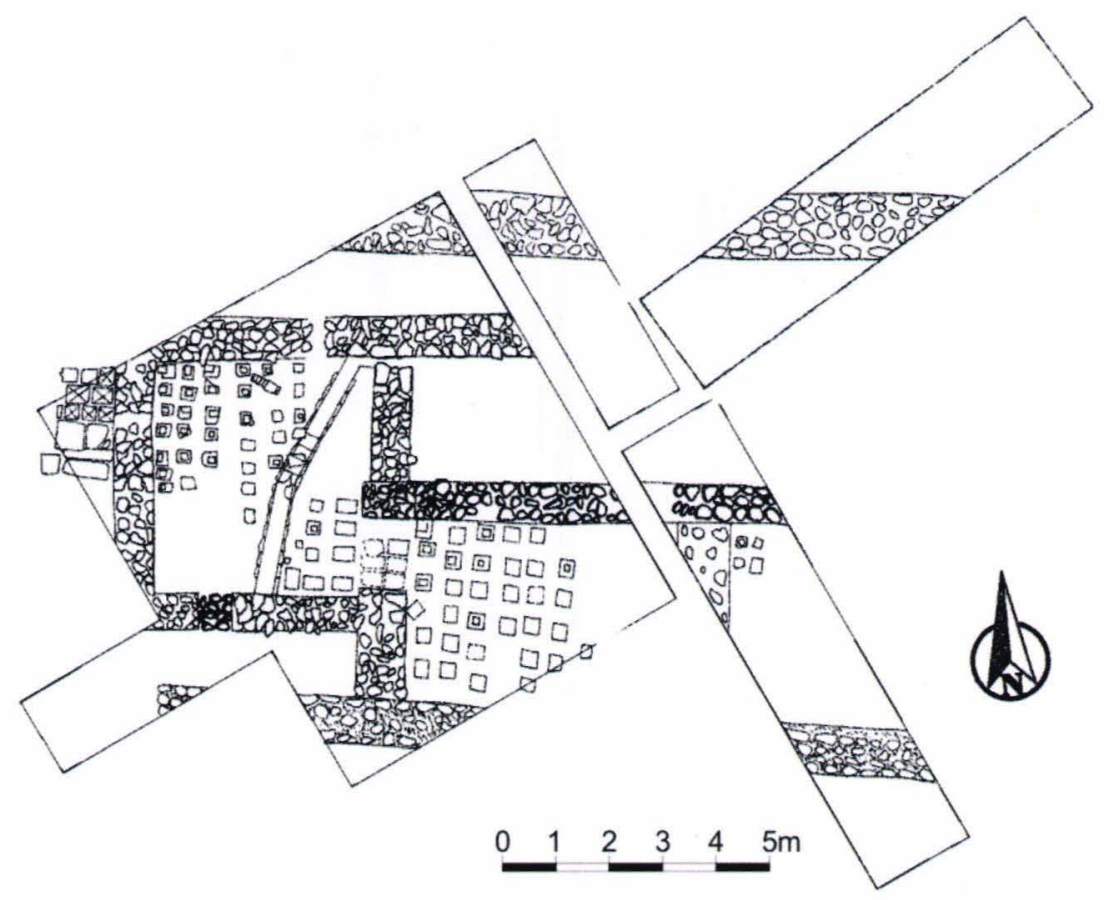

1.

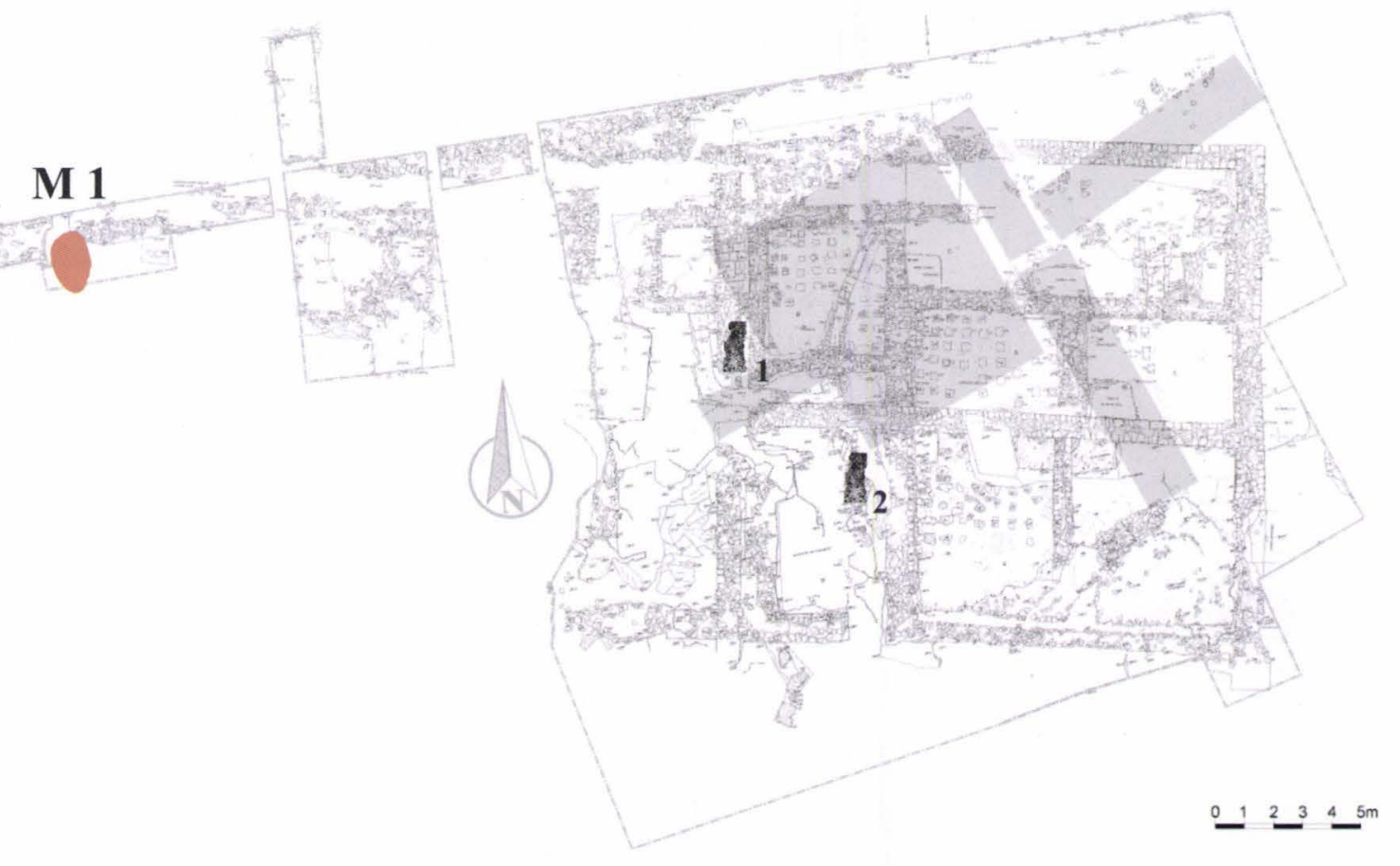

2.

1. Planul cercetărilor arheologice la finele campaniei 2001 (după Țentea, Voișian 2003, p. 456 fig. 2);

2. Planul cercetărilor din campania 2001 și planul final din anul 2003 (localizări: M1 - mormânt; A1, 2 - altare) 


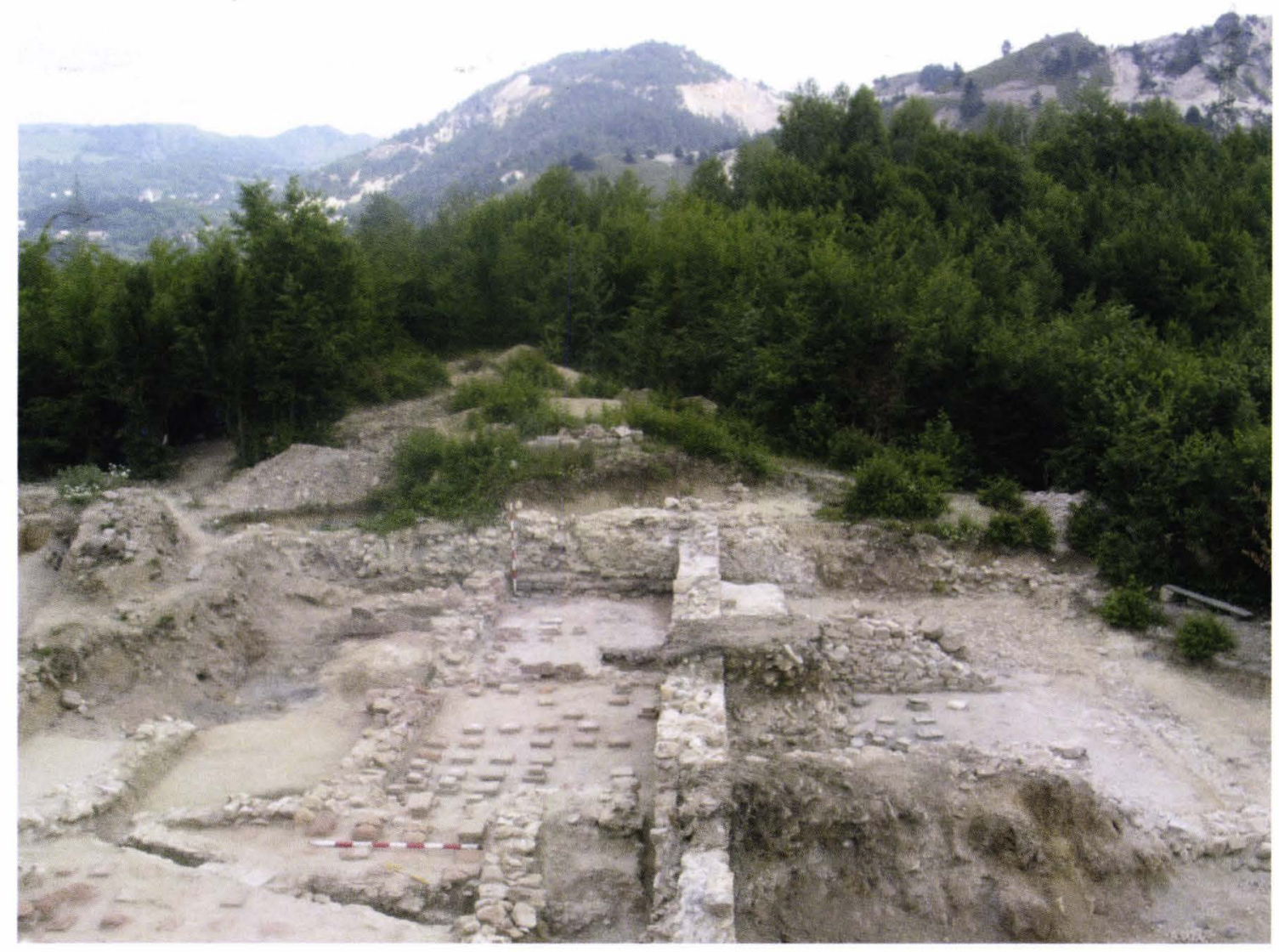

1.

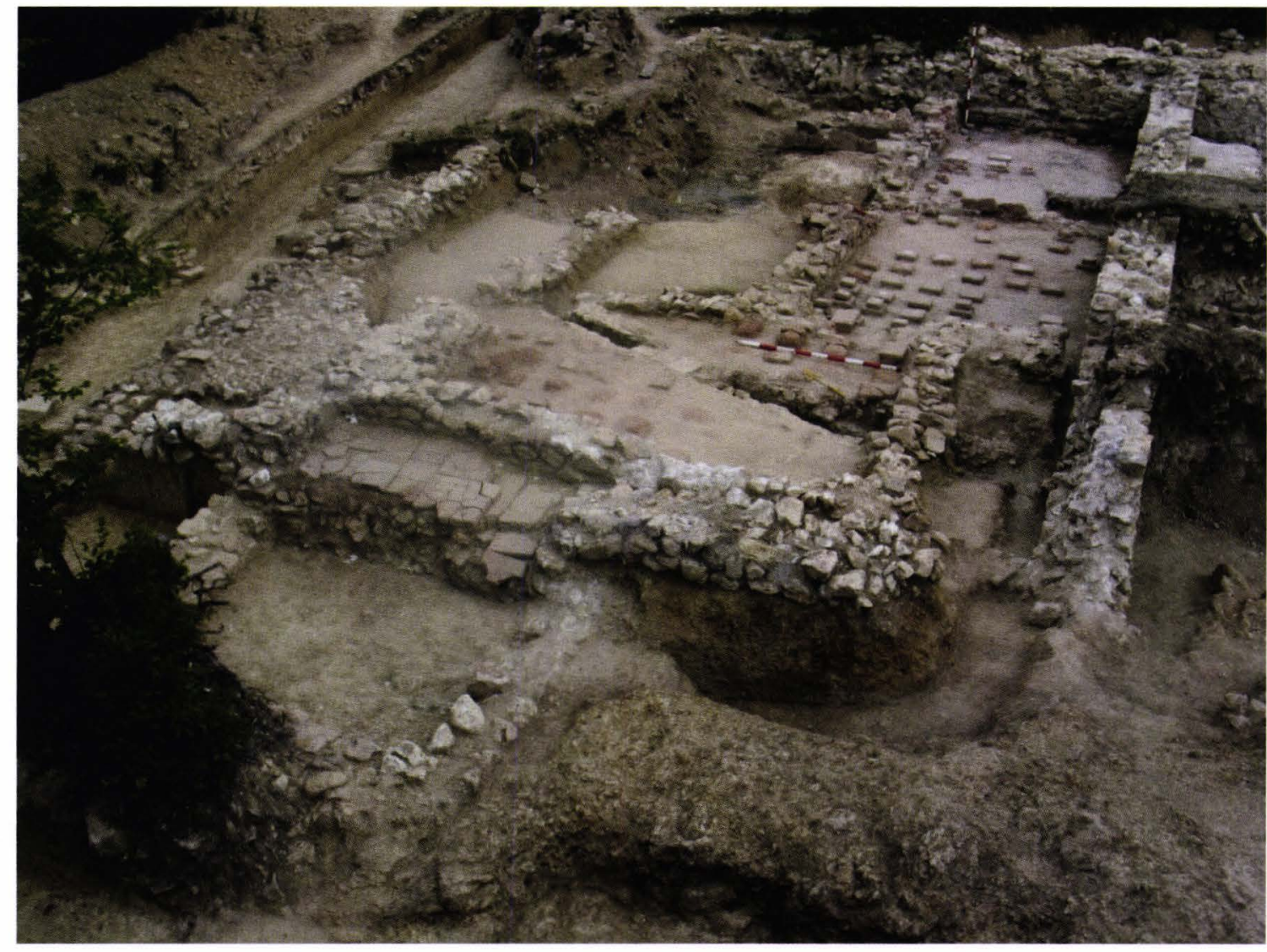

2.

1. Vedere generală dinspre vest; pe fundal se distinge Masivul Cârnic; 2. Vedere generală a zonei nordice a edificiului E2; în partea inferioara a imaginii se distinge bazinul din camera I și canalul c2 

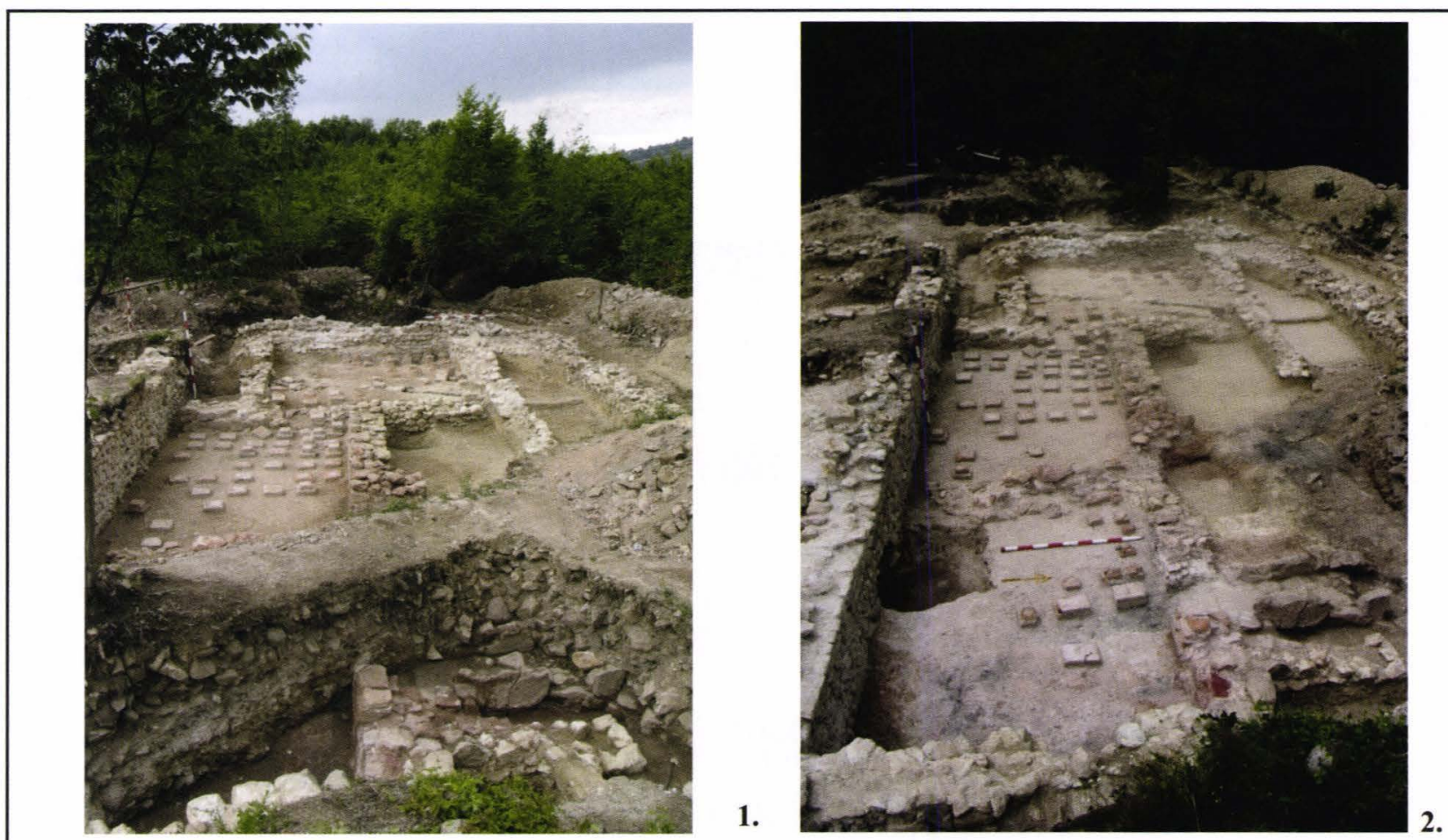

1.

2.

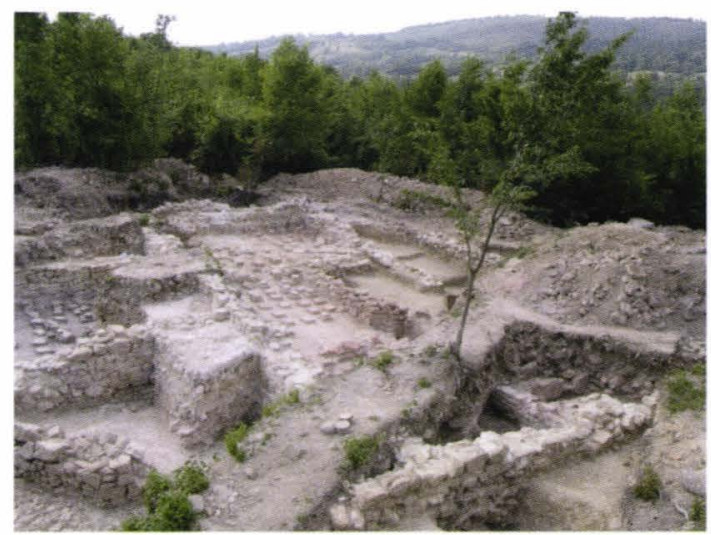

3.

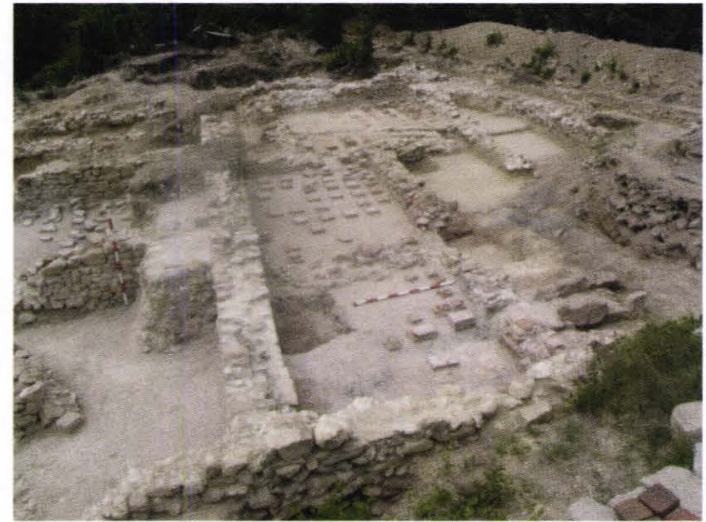

4.

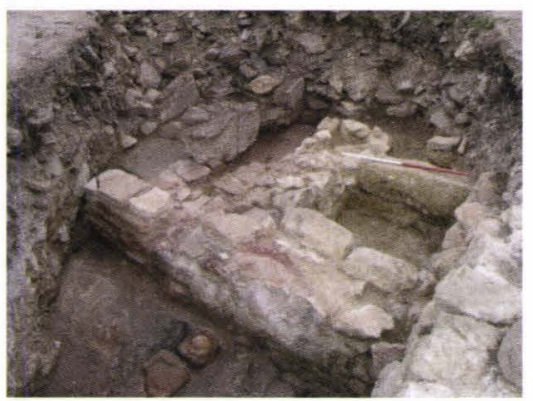

6.

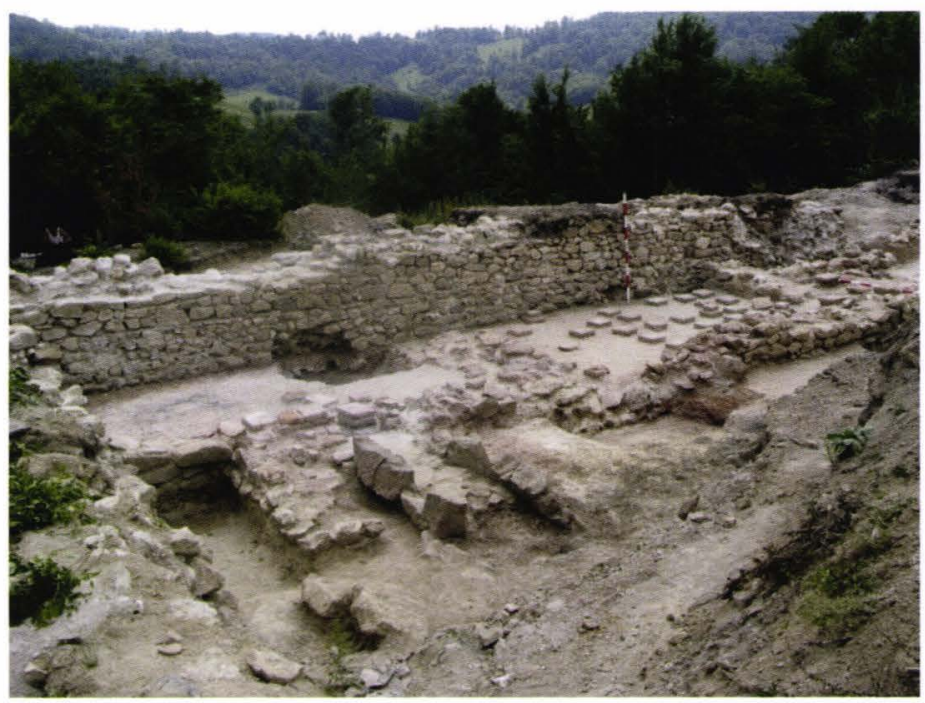

5.

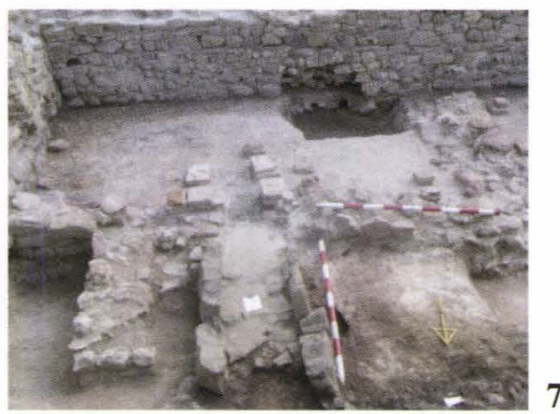

7.

1-3. Vedere generală a zonei nordice a edificiului; 4. Zona praefurnium (vedere dinspre nord); 5-7. Praefurnium (detalii) 


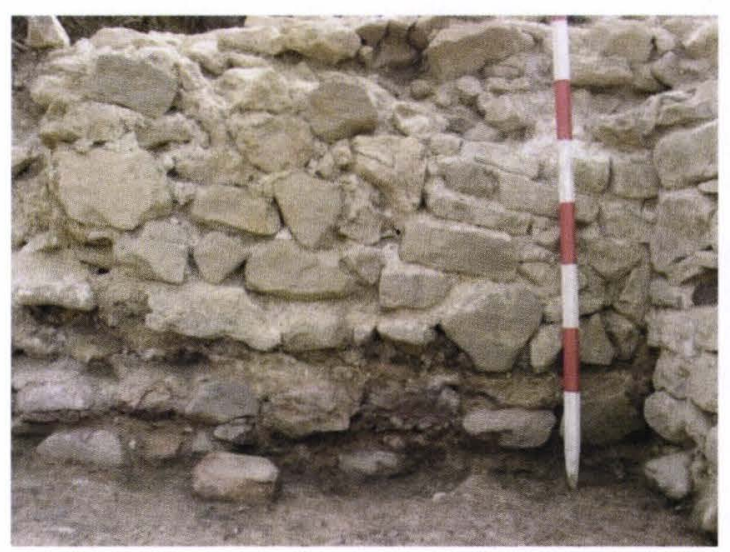

1.

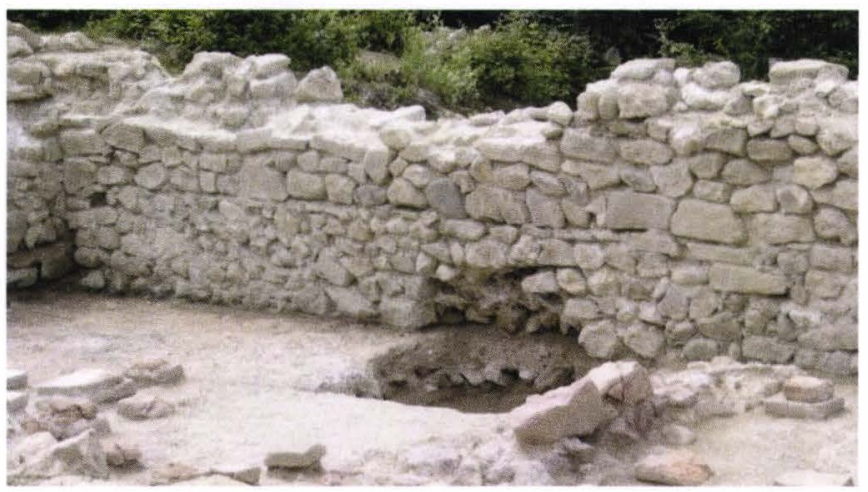

2.

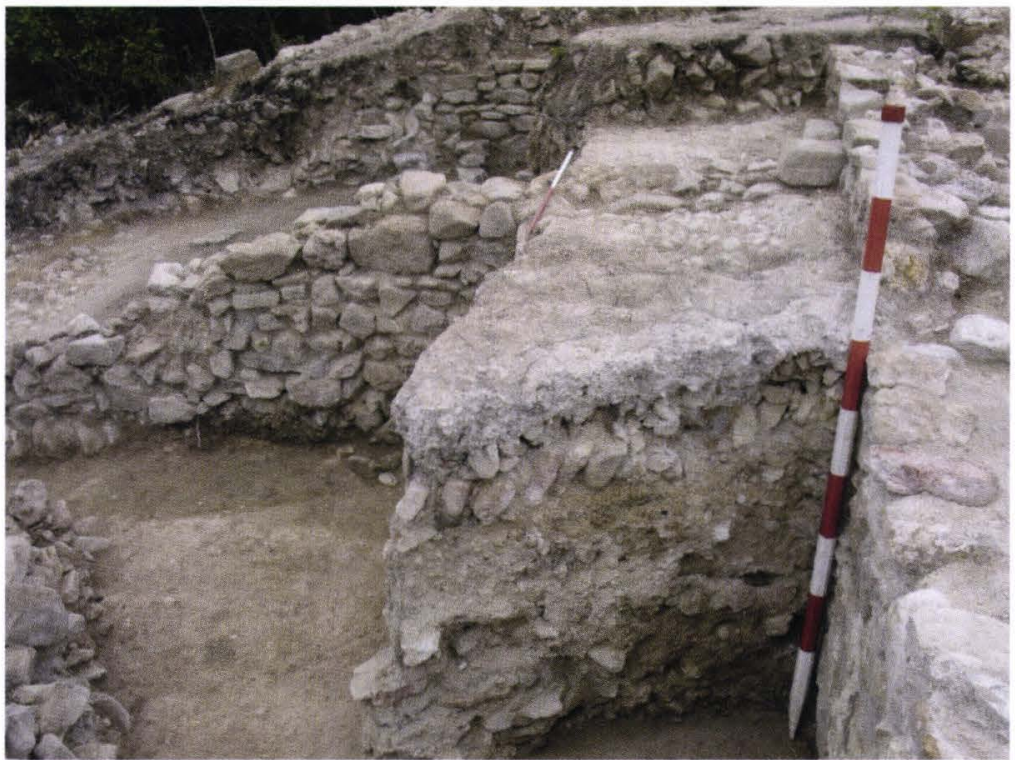

3.

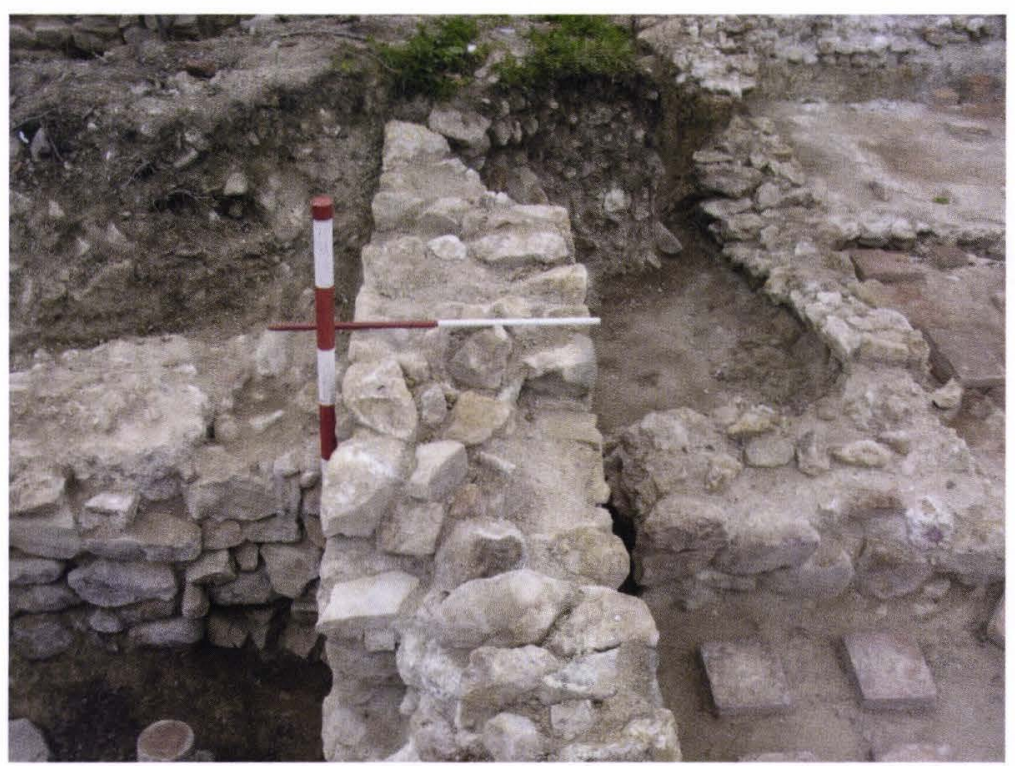

4.

1. Z9, detaliu privind succesiunea fazelor de construcție; 2. Imagine ilustrând construirea Z4 (faza 3) peste podeaua fazei anterioare; 3. Camera A', detaliu substrucției din faza a 3-a; 4. Intersectarea zidului Z4 (faza 3) cu traiectului zidului Z 5 (fazele 1-2) și refacerea acestuia în faza a 3-a doar în zona sudică (stânga imaginii) 


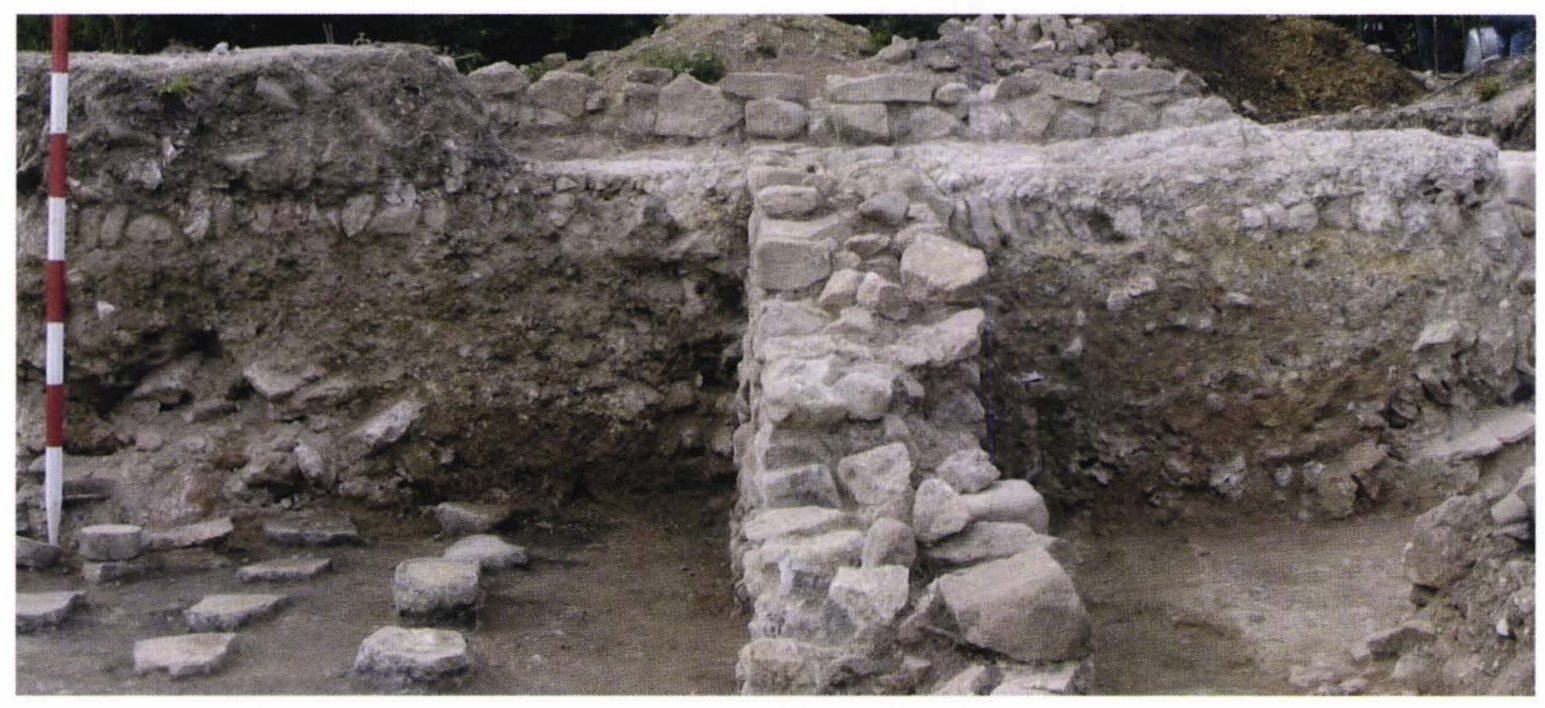

1.

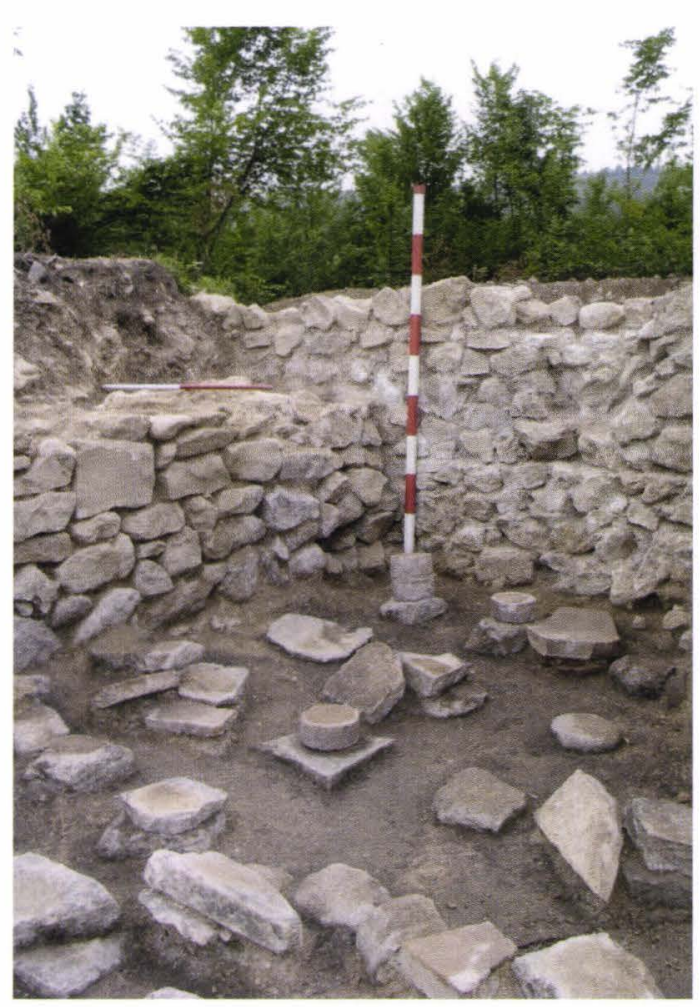

2.

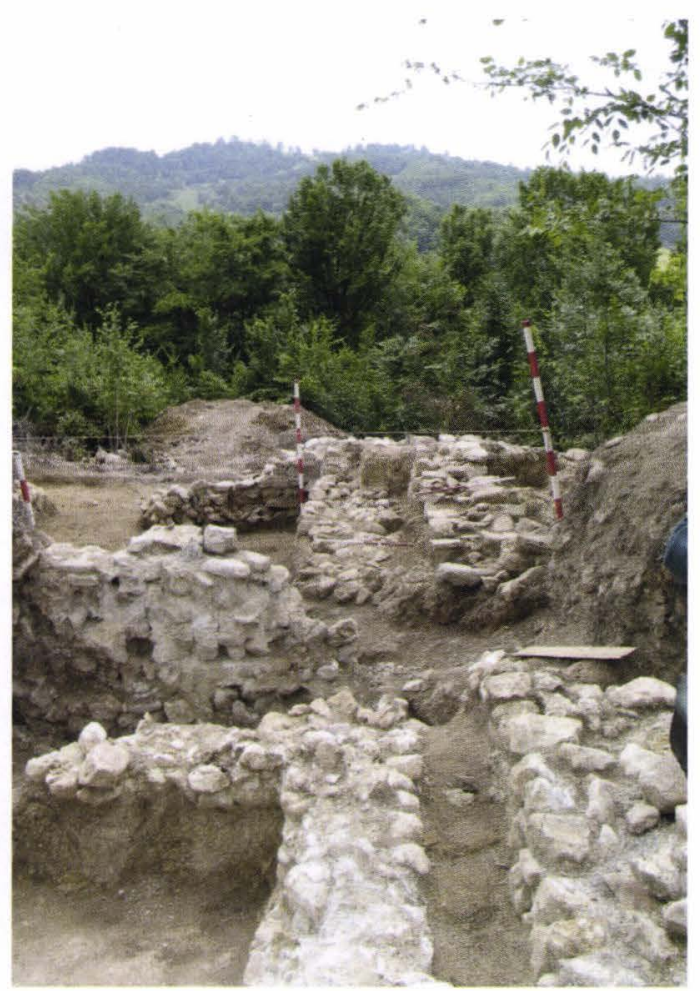

3.

1. Camerele A'și D’ (detalii stratigrafice ale succesiunii fazelor 2 și 3); 2. Baza pilonilor de susținere a pardoselii, realizați din lespezi de calcar; 3. Zidurile Z5 (faza 2, stânga) și Z 12 (faza 3, dreapta) 


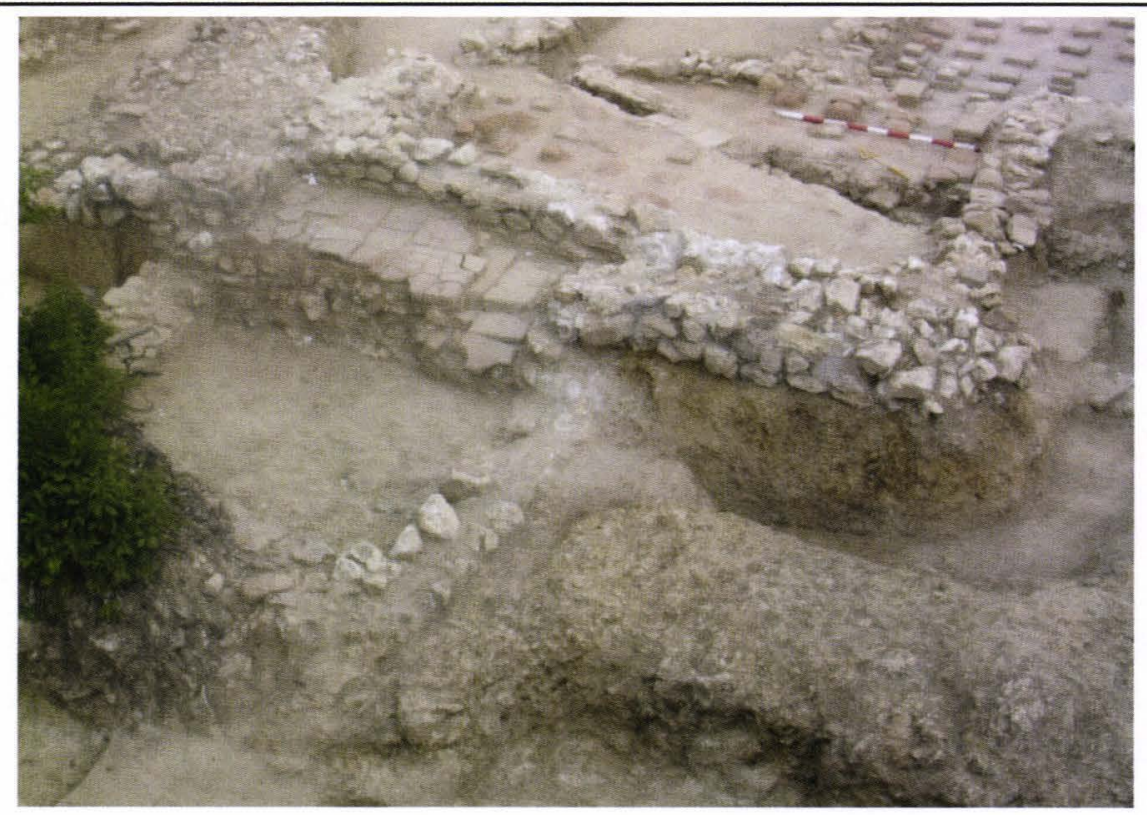

1.

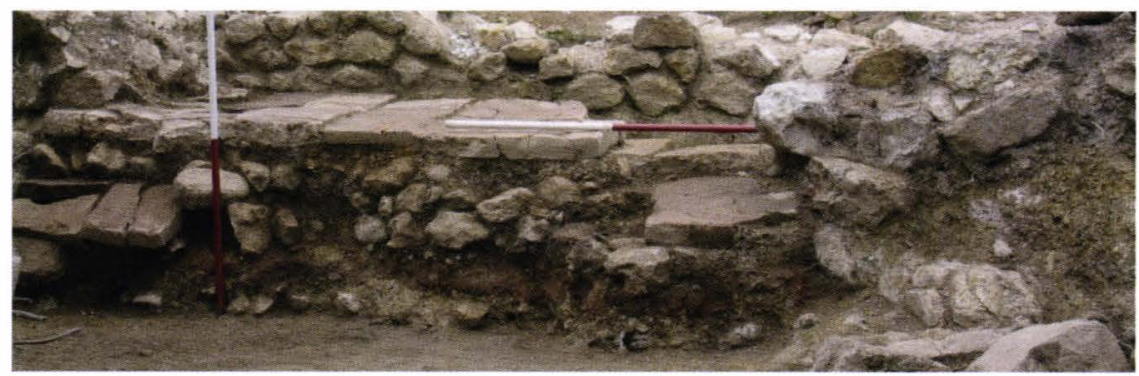

2.

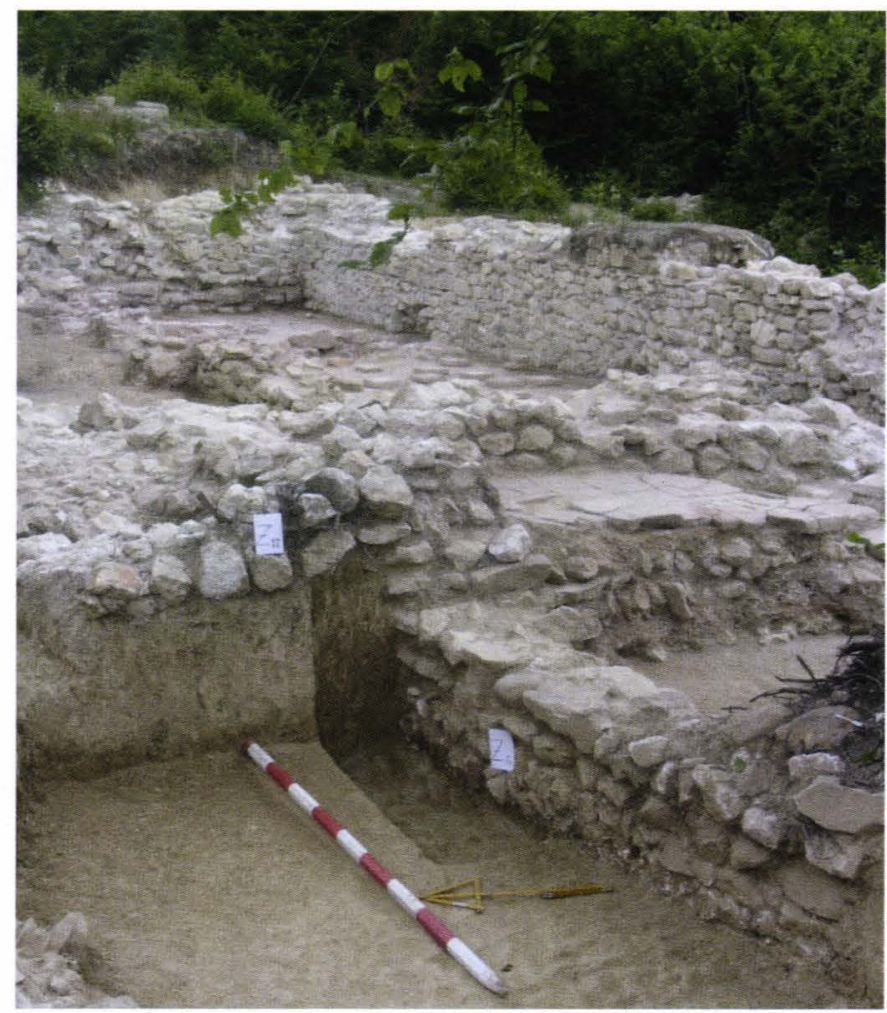

3.

Bazinul de apă rece din camera I: 1. Vedere generală dinspre sud-vest; 2. Reparații ale bazei bazinului (detaliu); 3. Zona de suprapunere a zidului Z 6 (faza 2) de către Z 12 (faza 3, moment în care bazinul este dezafectat, detaliu) 


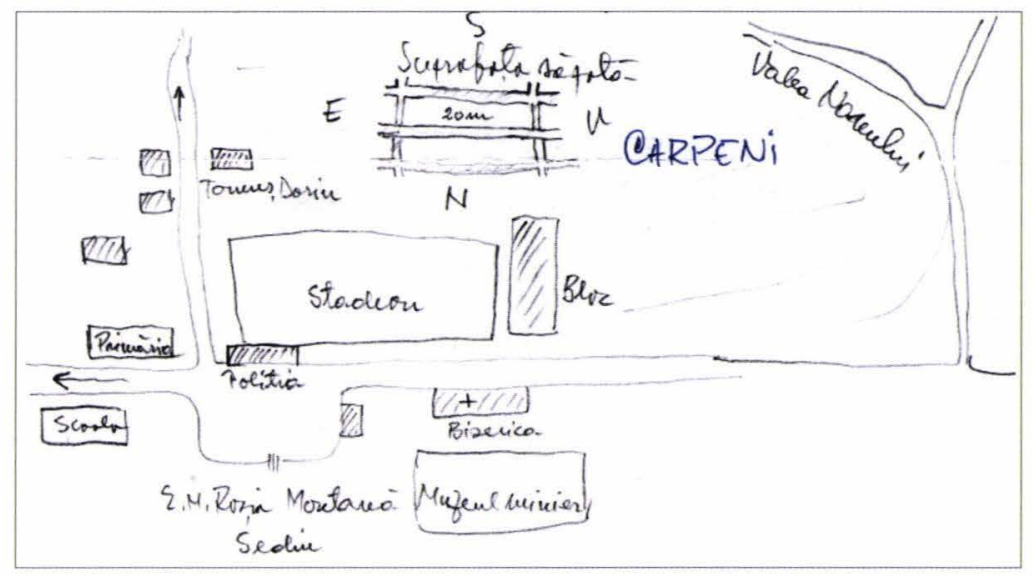

1.

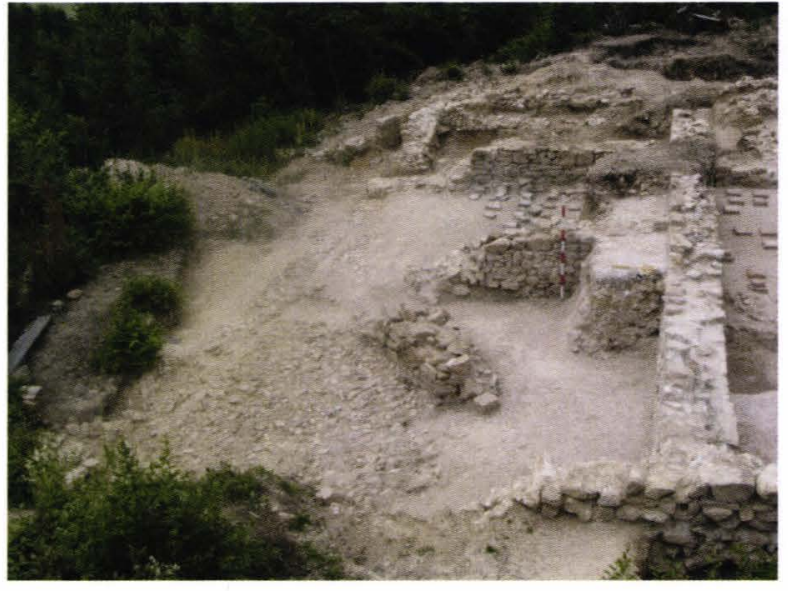

2.

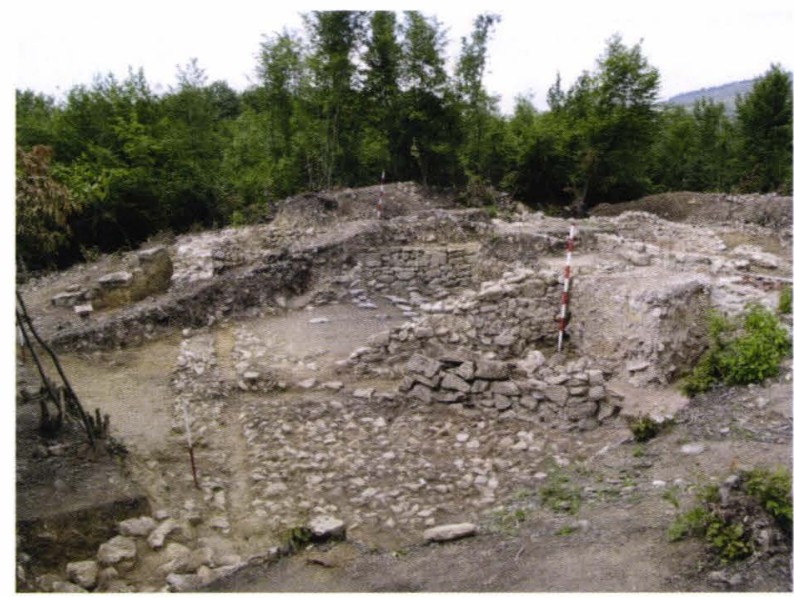

4.

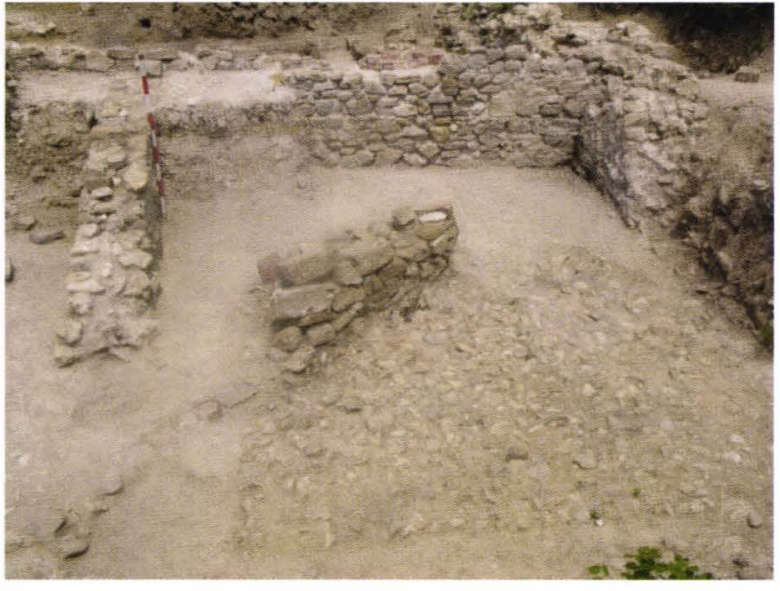

3.

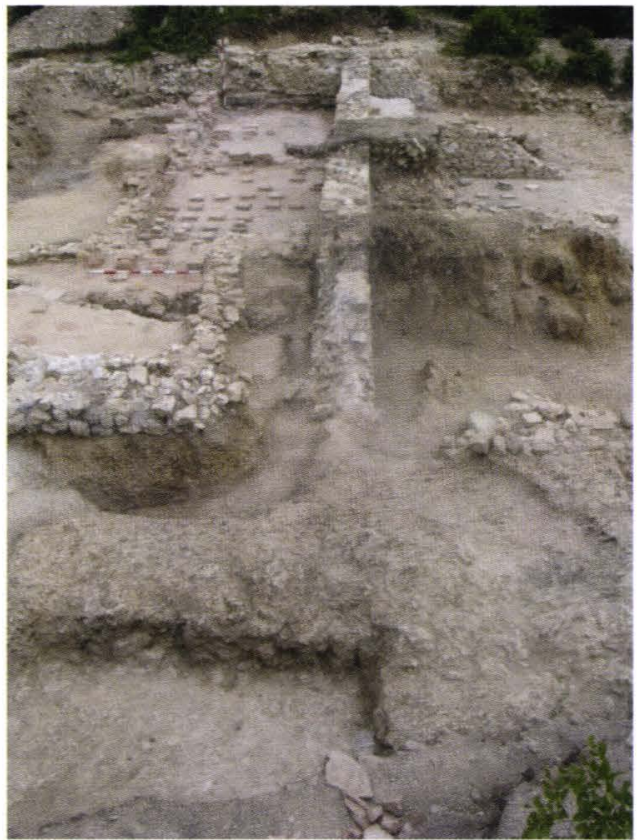

5.

1. Schiță privind amplasamentul intervențiilor cu caracter arheologic din anii ' 60 (desen A. Sîntimbreanu); 2-4. Imagini asupra urmările uneia dintre tranșeele din anii ' 60 în partea sudică a clădirii;

5. Distrugeri datorate intervențiilor din anii ‘ 60 în zona vestică a clădirii 


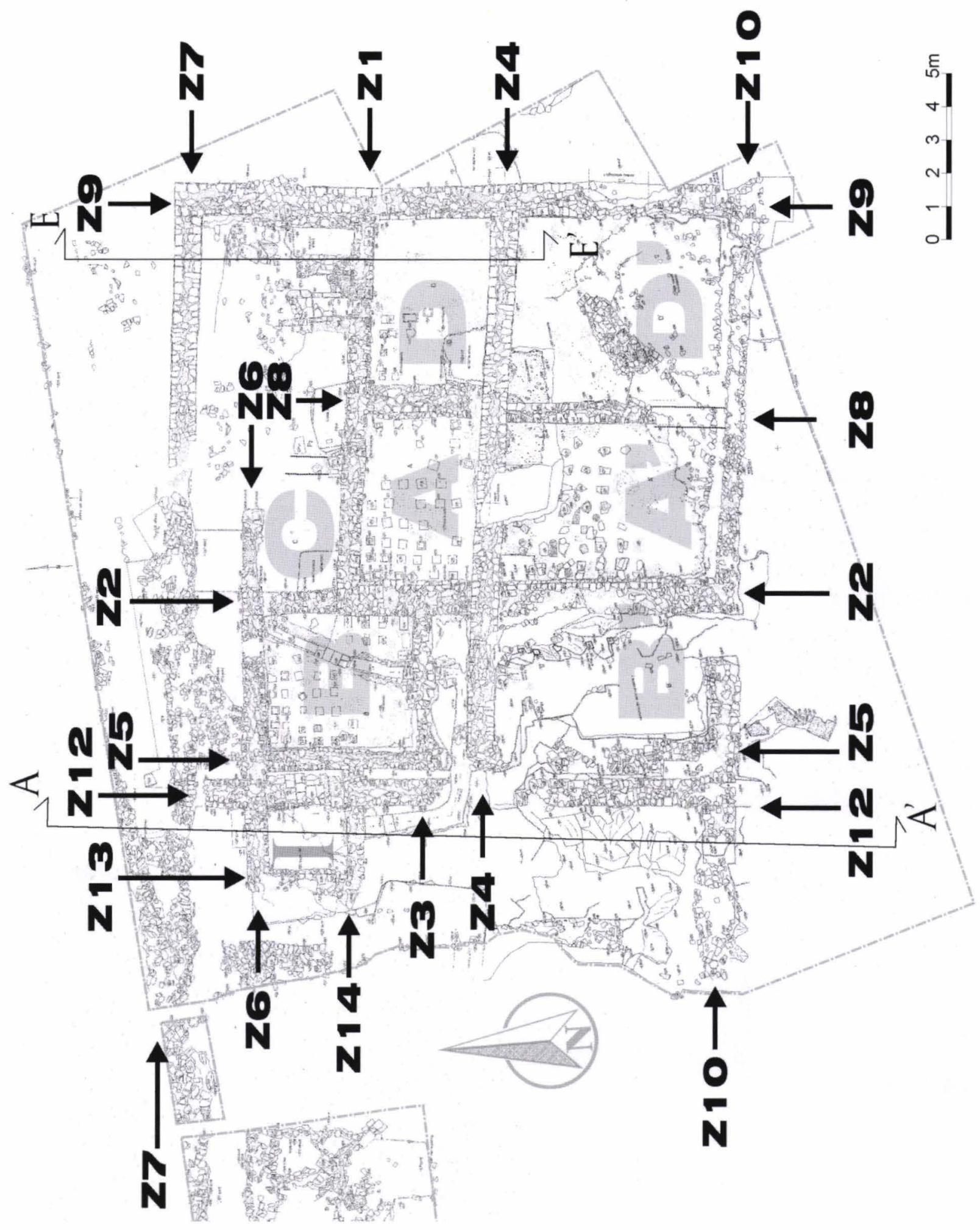

Edificiul E2, denumirile camerelor, zidurilor și marcarea axelor profilelor altimetrice AA`și EE`

Pl. X 


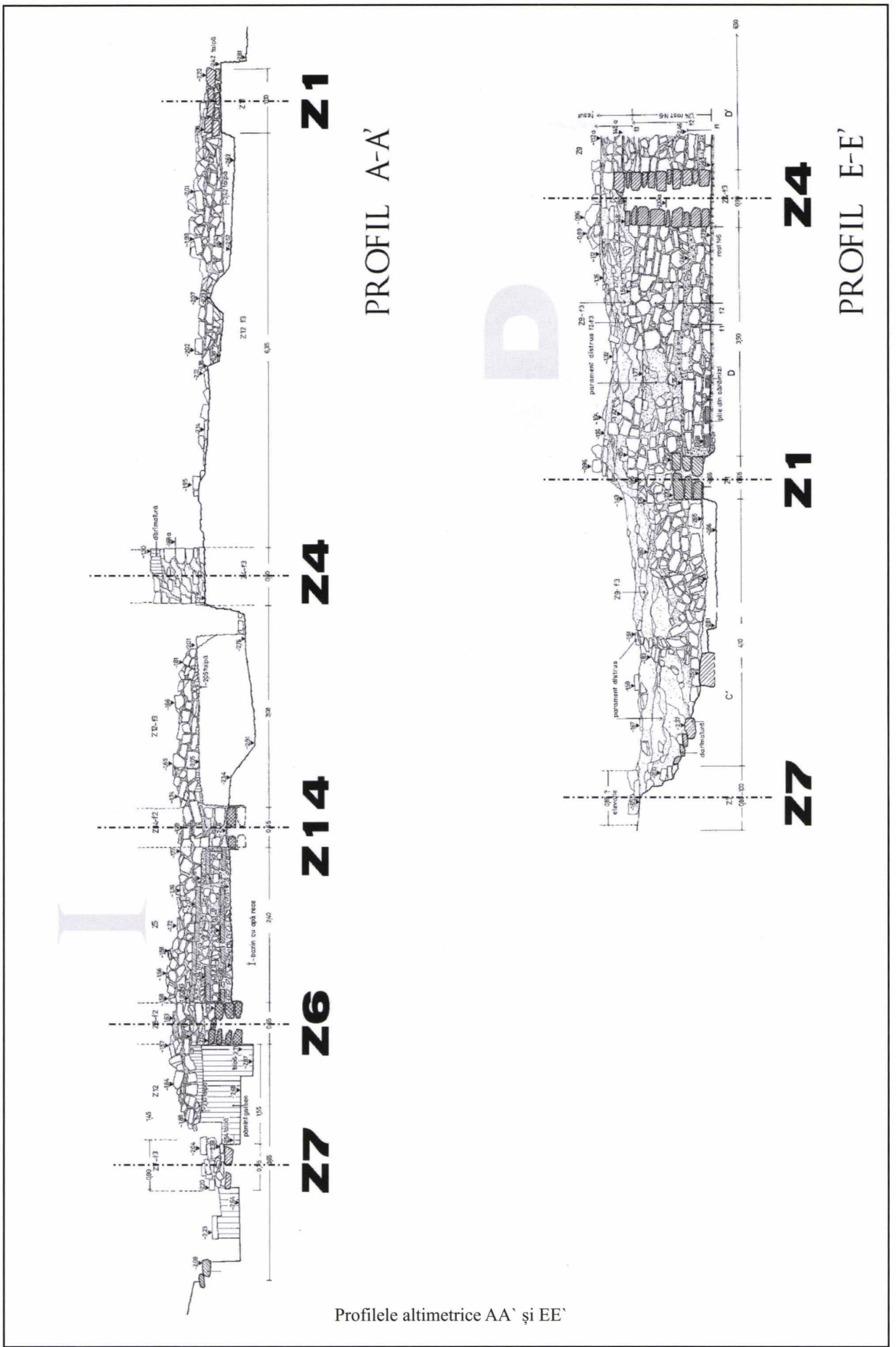

PI. XI 


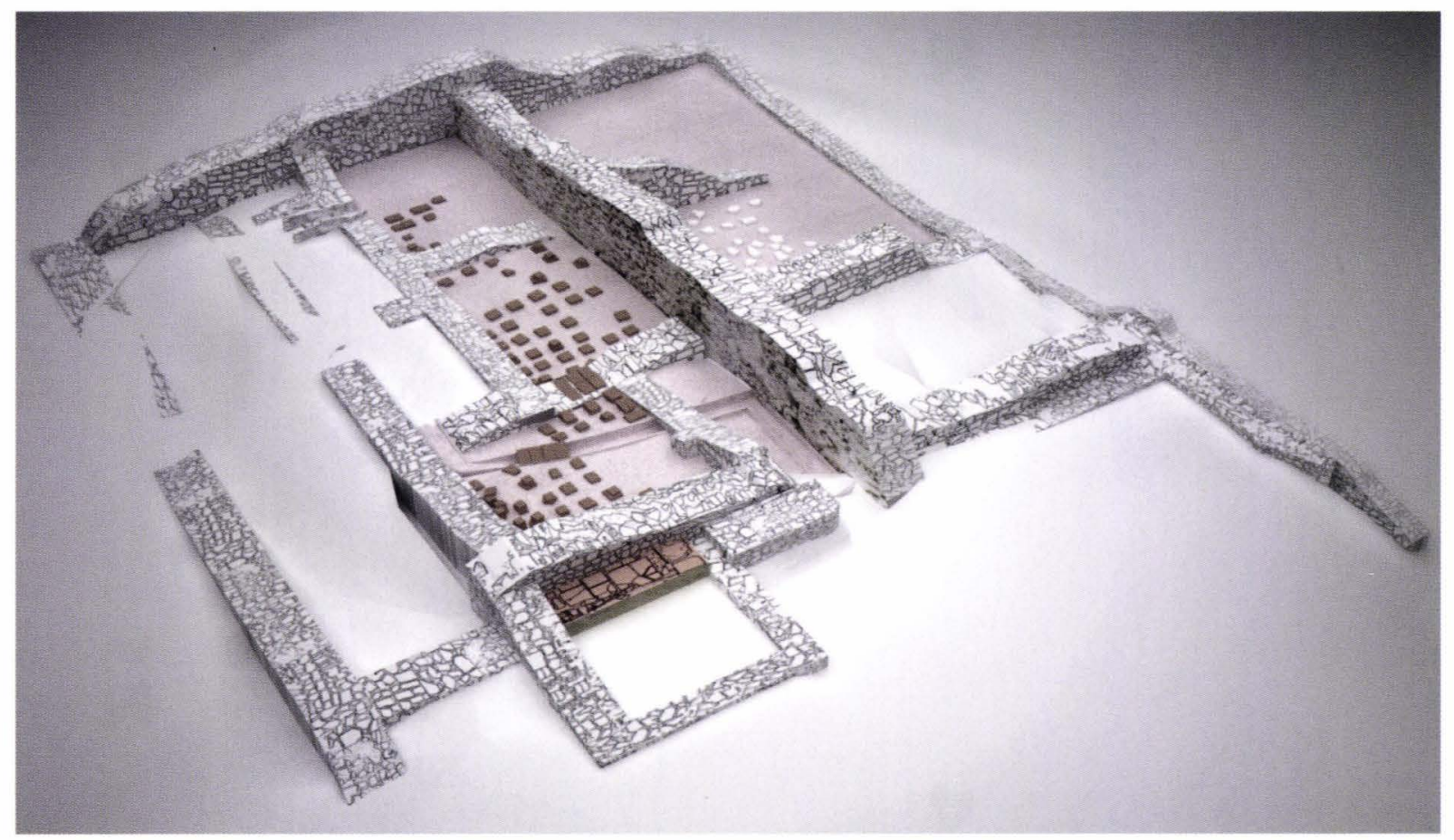

1.

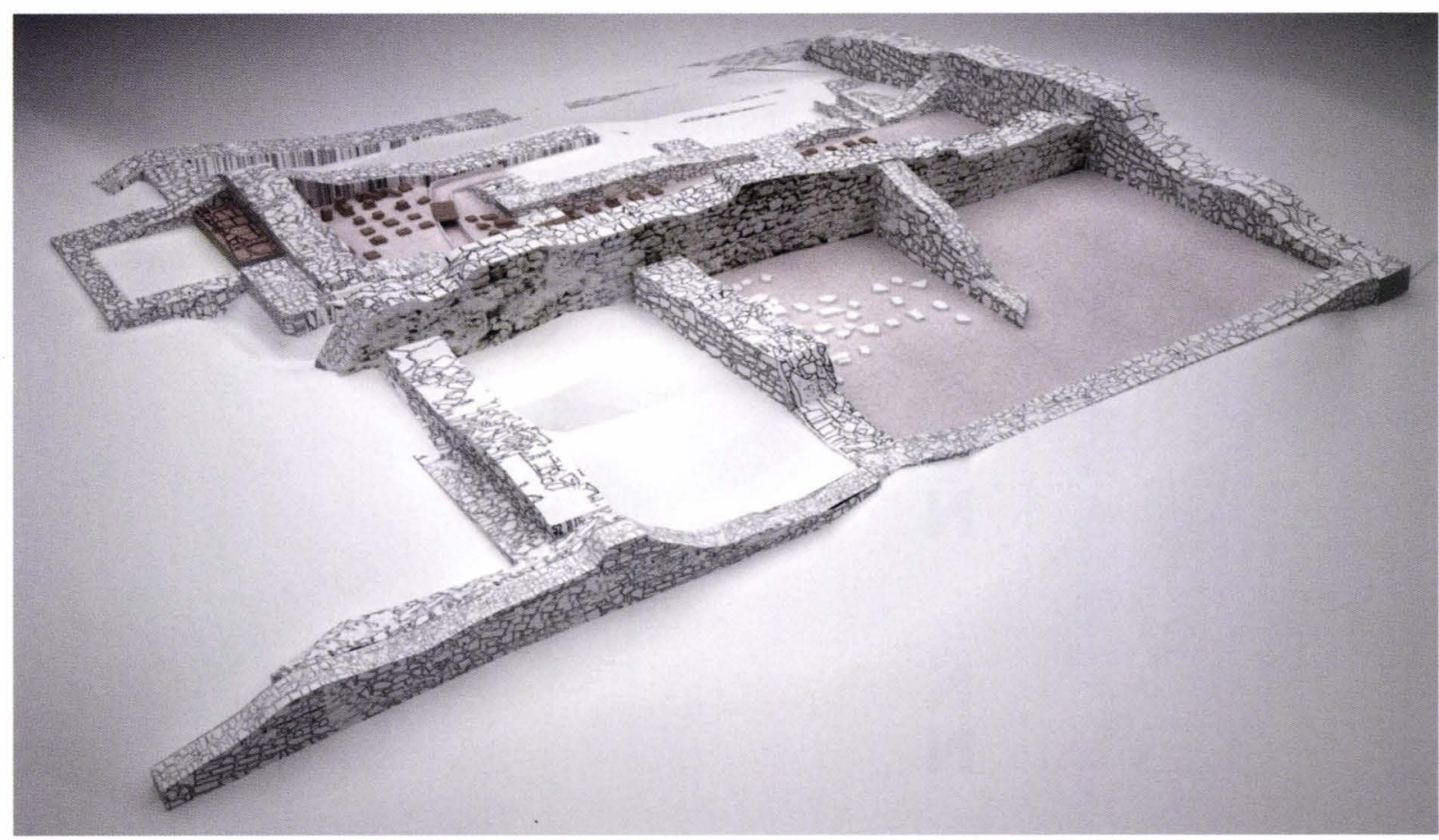

2.

Modelul 3D al edificiului: vedere dinpre nord (1) și dinspre vest (2) 


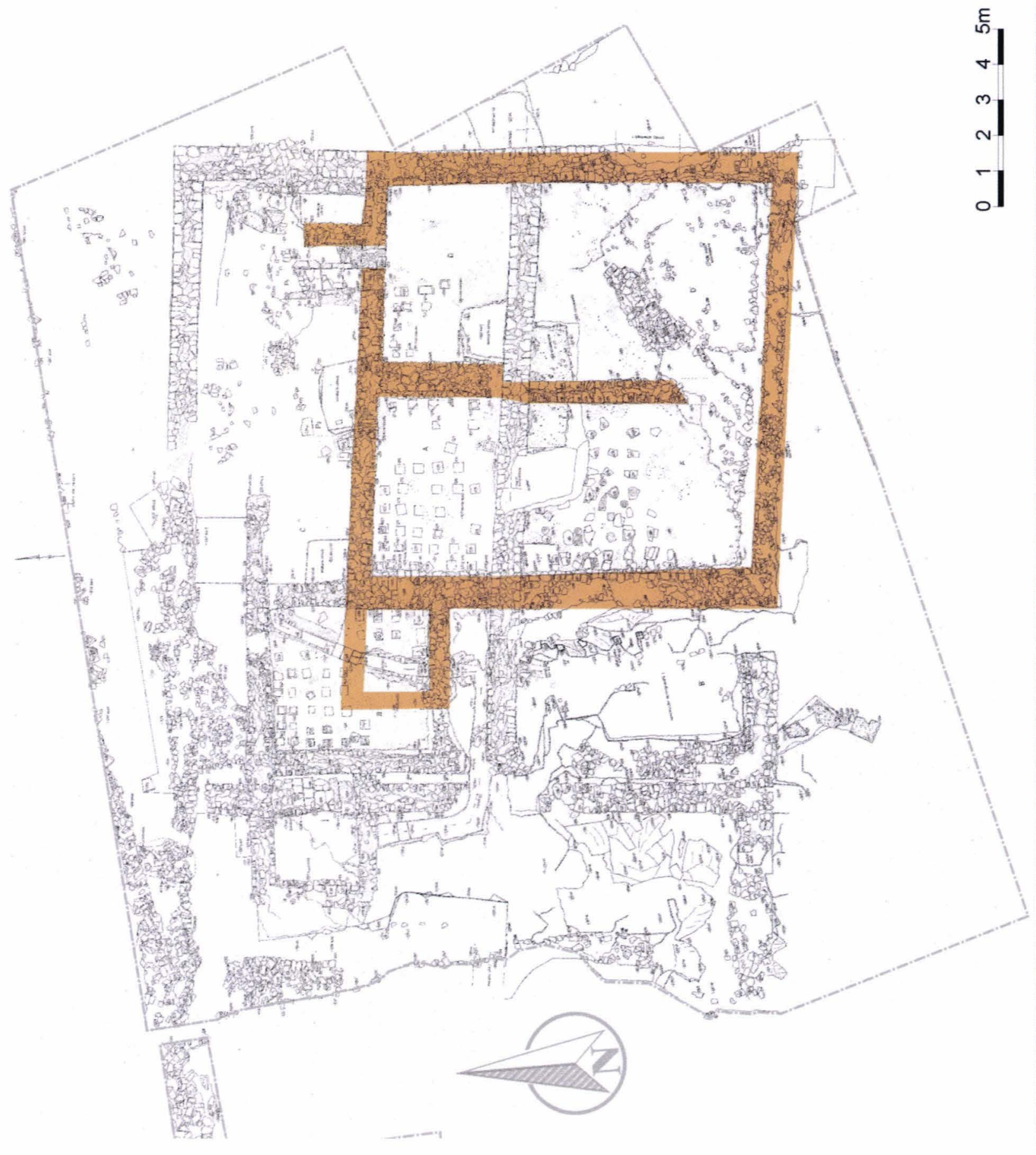

Planul fazei 1

PI. XIII 


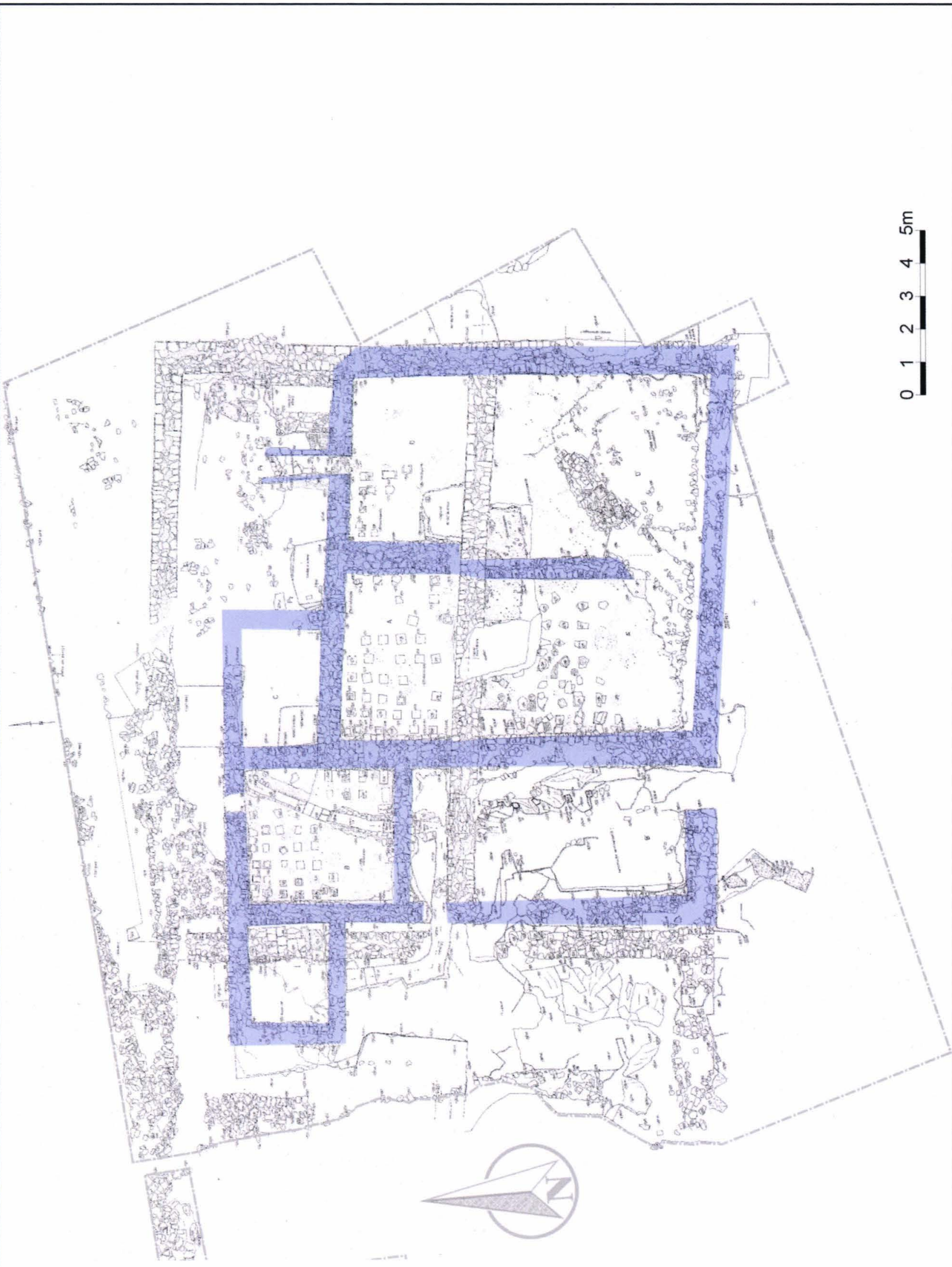

Planul fazei a 2-a 


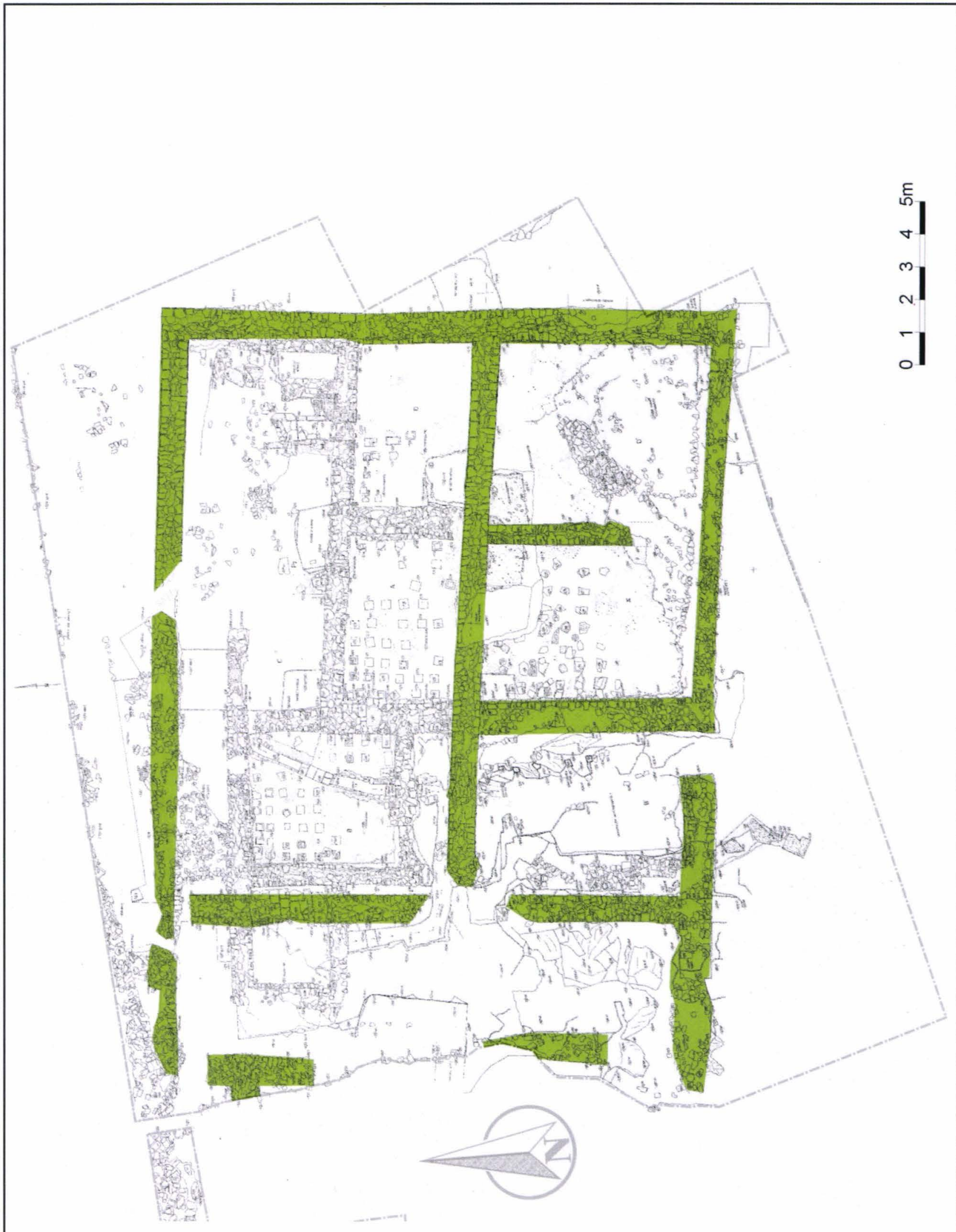

Planul fazei a 3-a 


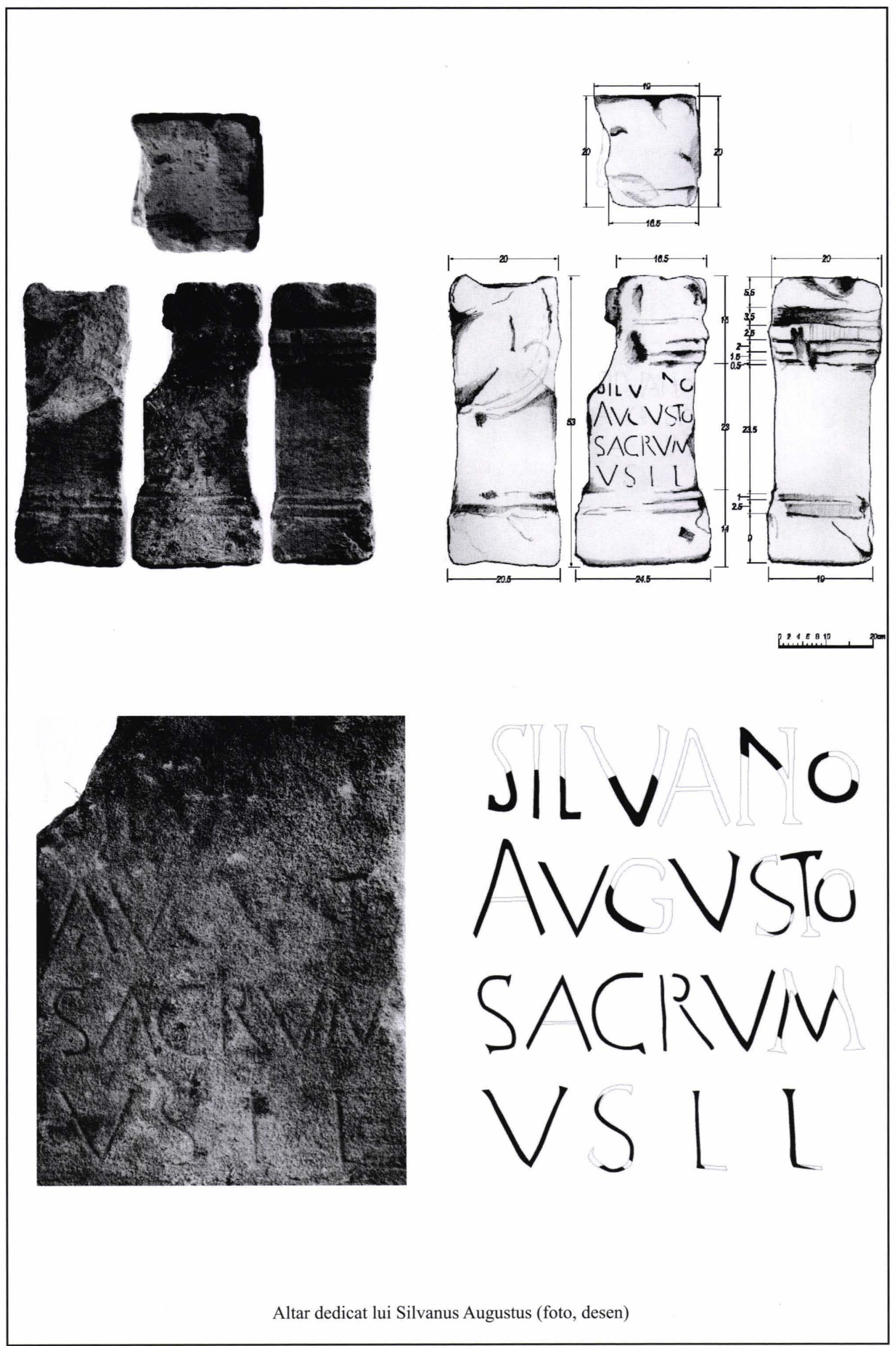




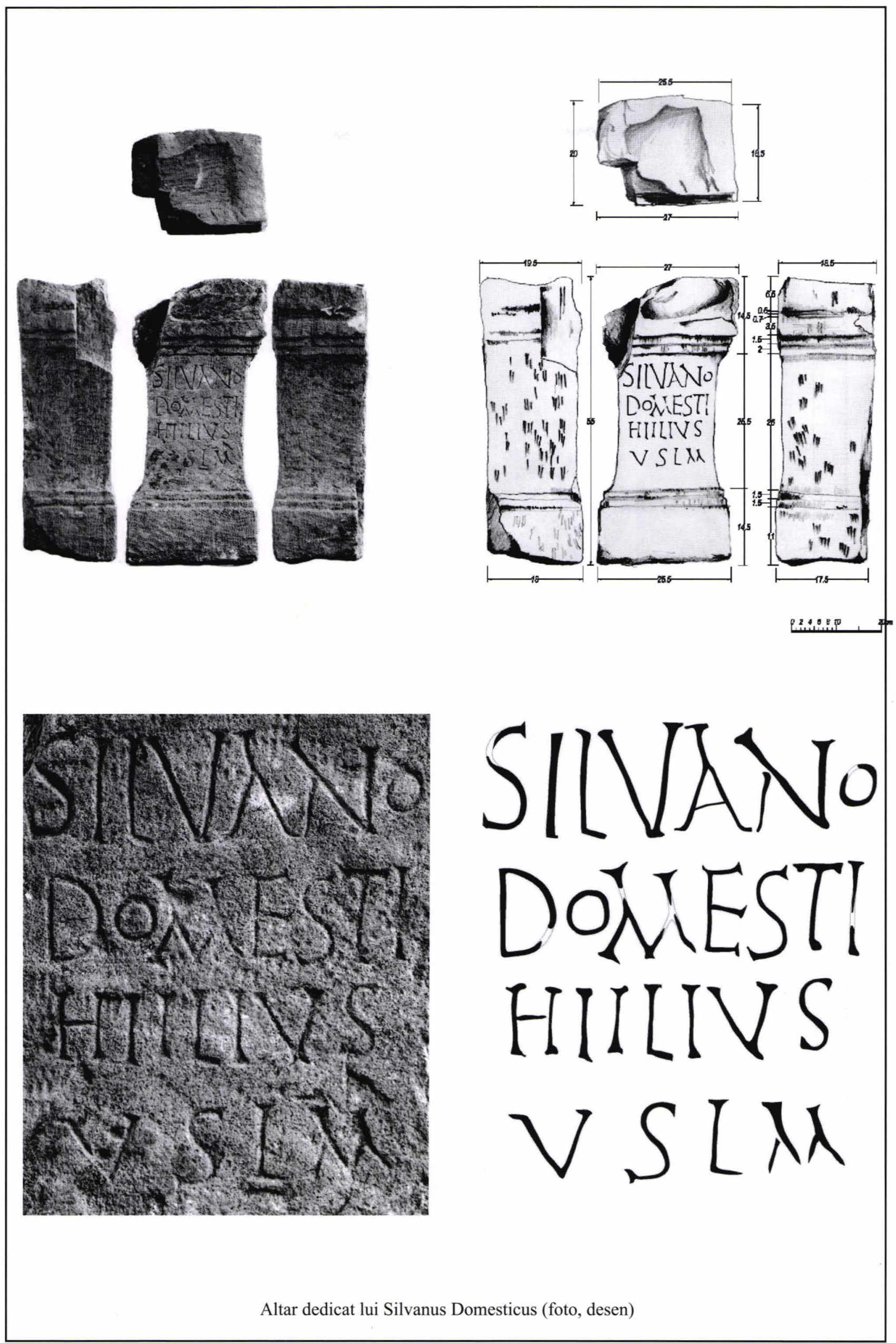




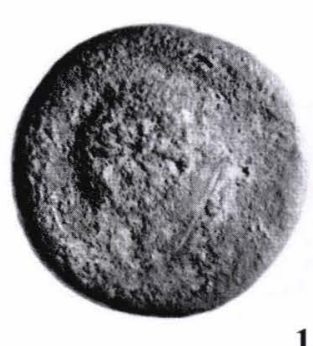

1.

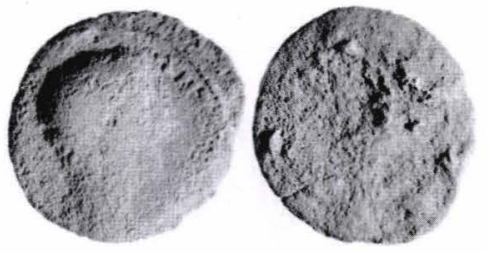

3.

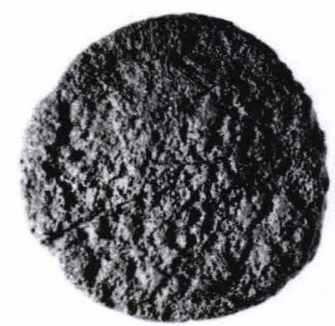

5.

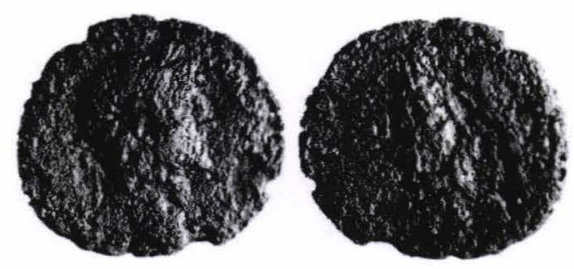

7.

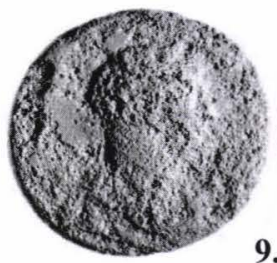

9.

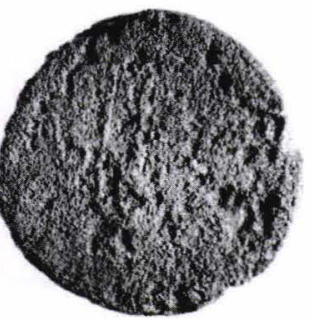

.
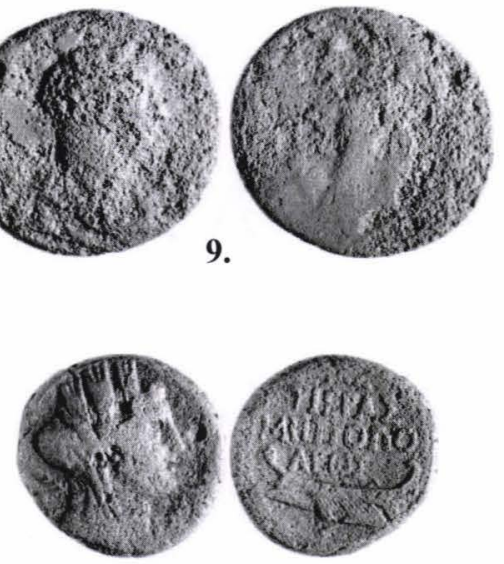

11.

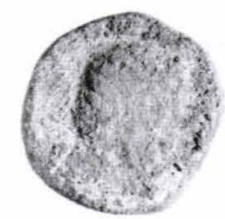

13.

Monetele descoperite în campaniile 2001-2003
2.
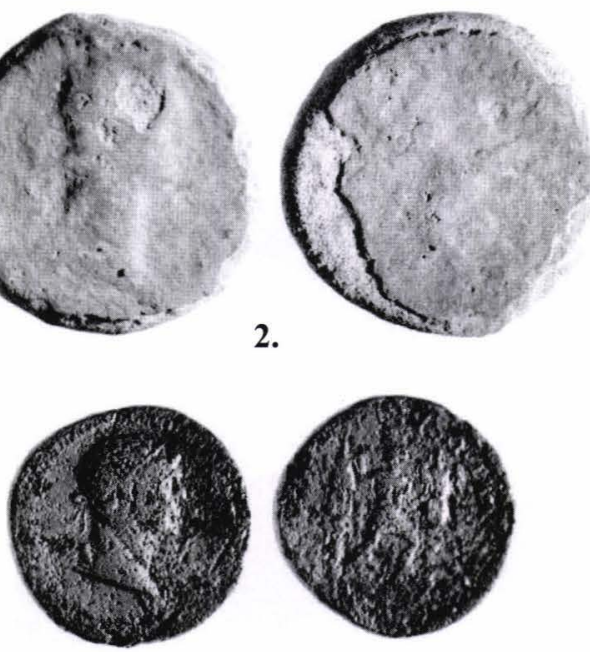

4.
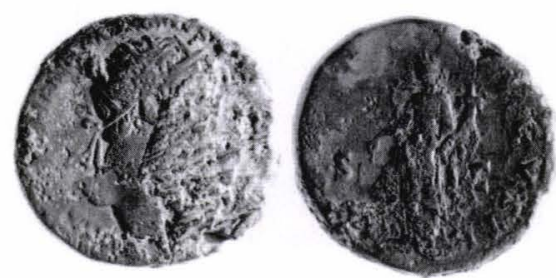

6.
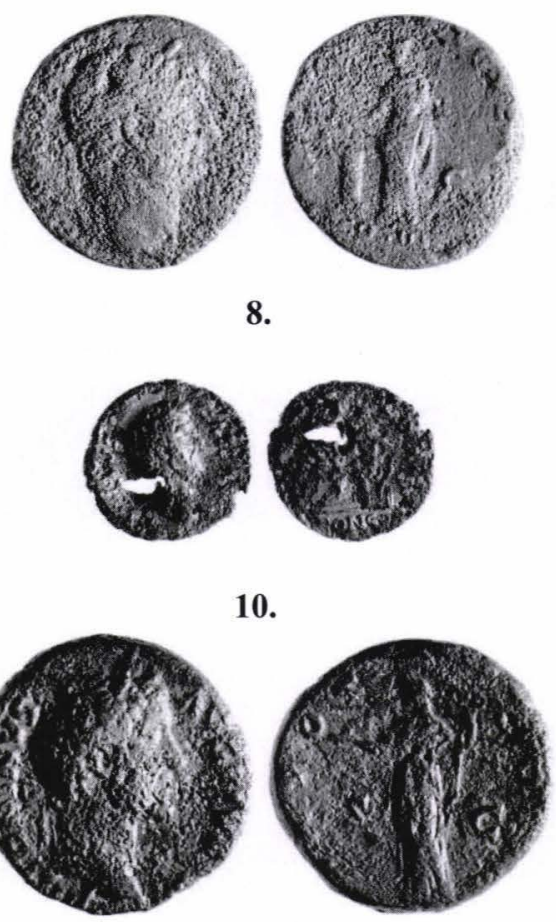

8.

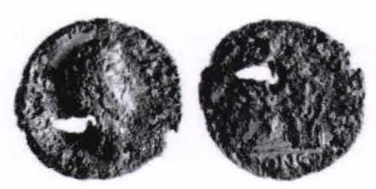

10.

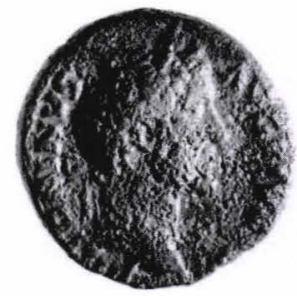

12.
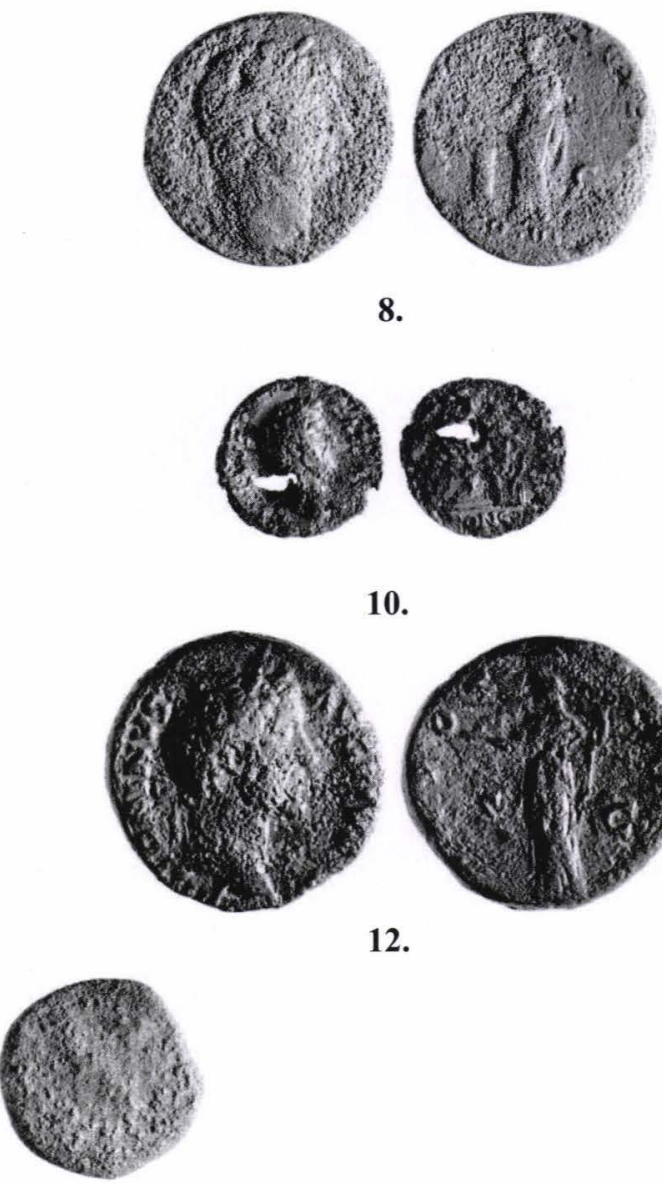


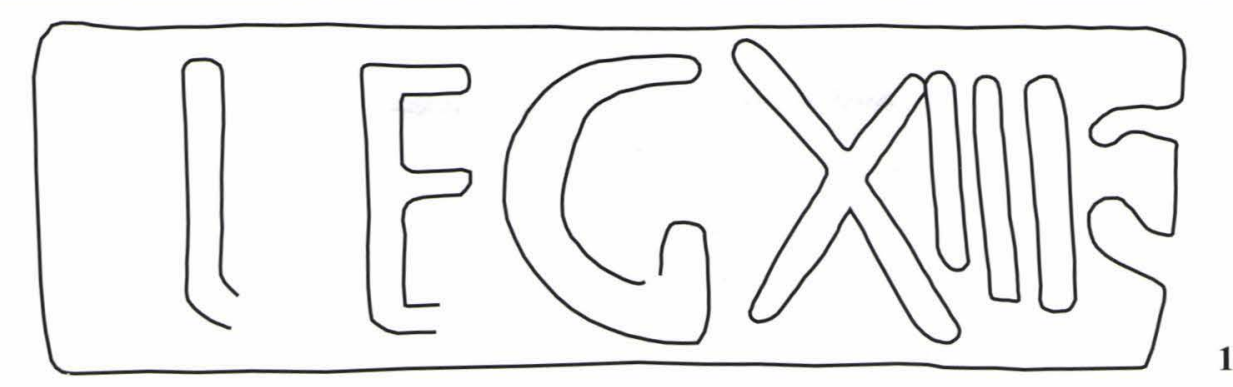

1.

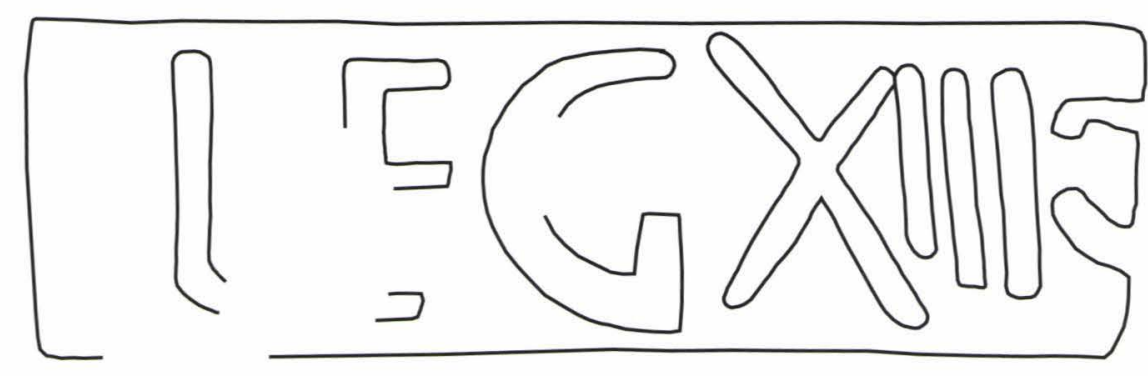

2.

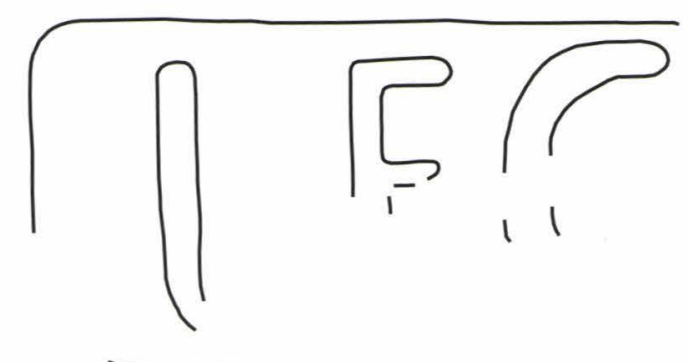

3.

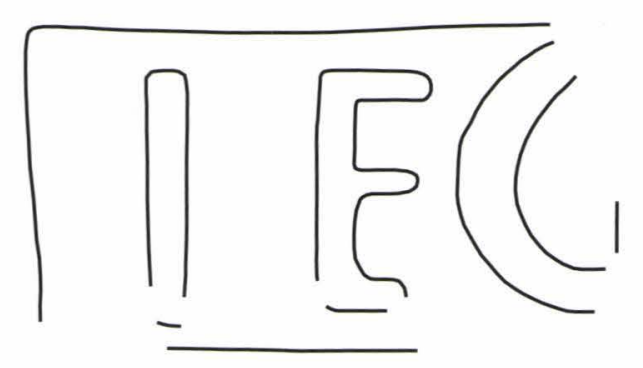

4.
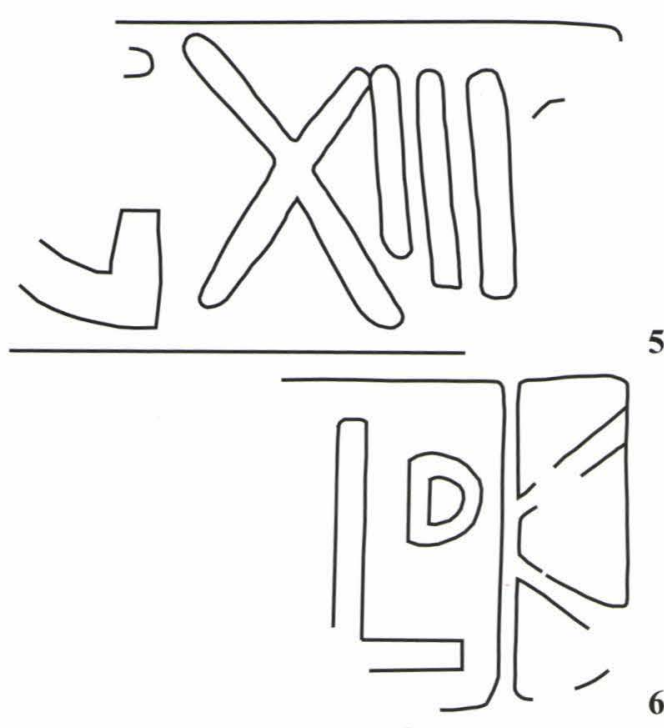

Ștampile tegulare descoperite în cursul campaniilor 2002-2003

PI. XIX 
